\title{
Ameliorated Antibacterial and Antioxidant Properties by Trichoderma harzianum Mediated Green Synthesis of Silver Nanoparticles
}

\author{
Narasimhamurthy Konappa ${ }^{1}$, Arakere C. Udayashankar ${ }^{2}$, Nirmaladevi Dhamodaran ${ }^{3}$, Soumya Krishnamurthy ${ }^{4}$, \\ Shubha Jagannath ${ }^{1}$, Fazilath Uzma ${ }^{1}$, Chamanahalli Kyathegowda Pradeep ${ }^{2}$, Savitha De Britto ${ }^{5,6}$, \\ Srinivas Chowdappa ${ }^{1, *}$ and Sudisha Jogaiah $5, * \mathbb{D}$
}

Citation: Konappa, N.;

Udayashankar, A.C.; Dhamodaran, N.; Krishnamurthy, S.; Jagannath, S.;

Uzma, F.; Pradeep, C.K.; De Britto, S.; Chowdappa, S.; Jogaiah, S.

Ameliorated Antibacterial and Antioxidant Properties by Trichoderma harzianum Mediated Green Synthesis of Silver Nanoparticles. Biomolecules 2021, 11, 535. https://doi.org/ 10.3390/biom11040535

Academic Editor: Carole Aimé

Received: 18 February 2021

Accepted: 31 March 2021

Published: 4 April 2021

Publisher's Note: MDPI stays neutral with regard to jurisdictional claims in published maps and institutional affiliations.

Copyright: (C) 2021 by the authors Licensee MDPI, Basel, Switzerland. This article is an open access article distributed under the terms and conditions of the Creative Commons Attribution (CC BY) license (https:/ / creativecommons.org/licenses/by/ $4.0 /)$.
1 Department of Microbiology and Biotechnology, Jnana Bharathi Campus, Bangalore University, Bengaluru 560 056, Karnataka, India; n.murthy10@gmail.com (N.K.); shubha.jagannath@gmail.com (S.J.); faziuzma@gmail.com (F.U.)

2 Department of Studies in Biotechnology, University of Mysore, Manasagangotri, Mysore 570 006, Karnataka, India; ac.uday@gmail.com (A.C.U.); pradeep77.gowda@gmail.com (C.K.P.)

3 Department of Microbiology, Ramaiah College of Arts, Science and Commerce, Bangalore 560 054, Karnataka, India; nirmaladevi1012@gmail.com

4 Department of Microbiology, Field Marshal K. M. Cariappa College, A Constituent College of Mangalore University, Madikeri 571 201, Karnataka, India; soumyanukrish@gmail.com

5 Laboratory of Plant Healthcare and Diagnostics, PG Department of Biotechnology and Microbiology, Karnatak University, Dharwad 580 003, Karnataka, India; savitha.debritto51@gmail.com

6 Division of Biological Sciences, School of Science and Technology, The University of Goroka, Goroka 441, Papua New Guinea

* Correspondence: srinivasbub@gmail.com (S.C.); jsudish@kud.ac.in (S.J.); Tel.: +91-836-2779533 (S.J.); Fax: +91-836-2747884 (S.J.)

Abstract: Biosynthesis of silver nanoparticles using beneficial Trichoderma harzianum is a simple, eco-friendly and cost-effective route. Secondary metabolites secreted by T. harzianum act as capping and reducing agents that can offer constancy and can contribute to biological activity. The present study aimed to synthesize silver nanoparticles using T. harzianum cell filtrate and investigate different bioactive metabolites based on LC-MS/MS analysis. The synthesized silver nanoparticles (AgNPs) from T. harzianum were characterized by ultraviolet-visible spectrophotometry, Fourier transform infrared spectrometry (FT-IR), energy-dispersive spectroscopy (EDS), dynamic light scattering (DLS), X-ray powder diffraction (XRD) and scanning electron microscopy (SEM). The surface plasmon resonance of synthesized particles formed a peak centered near $438 \mathrm{~nm}$. The DLS study determined the average size of AgNPs to be $21.49 \mathrm{~nm}$. The average size of AgNPs was measured to be $72 \mathrm{~nm}$ by SEM. The cubic crystal structure from XRD analysis confirmed the synthesized particles as silver nanoparticles. The AgNPs exhibited remarkable antioxidant properties, as determined by DPPH and ferric reducing antioxidant power (FRAP) assay. The AgNPs also exhibited broad-spectrum antibacterial activity against two Gram-positive bacteria (S. aureus and B. subtilis) and two Gramnegative bacteria ( $E$. coli and $R$. solanacearum). The minimum inhibitory concentration (MIC) of AgNPs towards bacterial growth was evaluated. The antibacterial activity of AgNPs was further confirmed by fluorescence microscopy and SEM analysis.

Keywords: silver nanoparticles; bioactive metabolites; antibacterial activity; MIC; antioxidant activity; T. harzianum filtrate

\section{Introduction}

Nanotechnology has evolved as an interesting part of research because of its ability to produce nanoparticles (NPs) possessing uniformity and special properties that make them valuable in optical sensors, drug delivery, catalysis, adsorption, water treatment and nanomedicine [1]. These NPs can be produced from different chemical, physical 
and biological processes. The chemical and physical approaches for the synthesis of nanoparticles are technically difficult and expensive. Chemical reduction, electrochemical and pyrolysis-based methods for the production of NPs are toxic, non-eco-friendly and difficult to perform. The requirement of strong reducing agents and toxic chemicals such as borohydride and hydrazine derivatives can increase the cost of production and result in hazardous wastes being released into the environment [2].

Biosynthetic methods have been used as a substitute for chemical and physical methods. The NPs derived from gold, silver and platinum are reported to have medical and pharmaceutical applications and are well documented to have important usages in magnetics, electronics, information storage and optoelectronics [3,4]. The biosynthesis of silver nanoparticles (AgNPs) has been proven by many researchers to be the best alternative when compared with physical and chemical methods of nanoparticle synthesis, as it is amore eco-friendly and cost-effective route [5]. The AgNPs are the most significant NPs used worldwide as they have several applications in clothing, dentistry, photography, coating of surgical devices, food industry, catalysis, optics, electronics, mirrors, prostheses, textiles, wound dressing, cosmetics and agriculture [6,7]. AgNPs synthesized by green methods are described to have various biological functions, making them useful in antidiabetic, anti-inflammatory, anticancer, antimicrobial, antiplasmodial, vector control and sensor applications, and also act as catalysts [8,9].

The ever-increasing problem of antibiotic resistance in pathogenic microorganisms challenges the research community to develop cost-effective processes for synthesizing novel antimicrobial agents [10]. Silver NPs cause the destruction of microorganisms by attacking and damaging their negatively charged cell walls. Further disruption of membrane permeability and deactivation of enzymes leads to cell lysis and death [11]. The activity of AgNPs depends on the monovalent ionic silver $\left(\mathrm{Ag}^{+}\right)$, which enters into the target microbial cells and prevents microbial growth by suppressing the activity of respiratory enzymes and electron transport mechanisms [12]. It has also been found that the AgNPs affect the cellular membrane permeability [13].

Microorganisms have been investigated as potential biofactories for nanoparticle biosynthesis [14]. Current research efforts focus on the synthesis of NPs using microbes such as algae [15], fungi [2], yeast [16] and bacteria [17] or using the byproducts of microbial metabolism, which are active reducing and stabilizing agents. Among the various microorganisms, fungal synthesis of AgNPs is simple and effective; however, the process parameters need to be optimized accordingly to attain the desired monodispersity, stability, biocompatibility and other critical properties of the particles [2,18]. Among the various fungi used for biosynthesis of AgNPs are Fusarium oxysporum [19], Fusarium semitectum [19], Aspergillus sp. [20], Trichoderma harzianum [3,21], Beauveria bassiana [22], Penicillium sp. [23], Cladosporium sp. [24] and basidiomycetes [7]. In this study, we have investigated the use of the fungus Trichoderma harzianum (MK611661) in the synthesis of extracellular AgNPs. The bioactive metabolites present in T. harzianum culture filtrate were identified using LC-MS/MS. Further, AgNPs were synthesized from T. harzianum filtrate using $\mathrm{AgNO}_{3}$, and the characterization of synthesized AgNPs was based on microscopic and spectroscopic methods, including ultraviolet-visible spectrophotometry, Fourier transform infrared spectrometry (FT-IR), energy-dispersive spectroscopy (EDS), X-ray powder diffraction (XRD) and scanning electron microscopy (SEM). Further, their potential antioxidant and antimicrobial activities were evaluated.

\section{Materials and Methods}

\subsection{Isolation of Trichoderma harzianum and Biomass Preparation}

Trichoderma harzianum was isolated from rhizosphere soil on potato dextrose agar (PDA) medium at $28{ }^{\circ} \mathrm{C}$. The isolated fungus was identified morphologically by lactophenol cotton blue mounting, and molecular identification was based on the internal transcribed spacer (ITS) sequencing. Based on the sequence, the fungus was identified as T. harzianum, and the sequence was deposited in National Center for Biotechnology Information (NCBI) 
under GenBank accession number MK611661.Mycelial disks (5 mm) of T. harzianum culture were inoculated into $100 \mathrm{~mL}$ of potato dextrose broth (PDB) medium in $250 \mathrm{~mL}$ Erlenmeyer flasks and incubated at $25 \pm 2{ }^{\circ} \mathrm{C}$ for 5 days on a rotary shaker at $150 \mathrm{rpm}$. After 5 days of incubation, the fungal mycelium mass was separated by filtration using Whatman No. 1 filter paper. Following harvest, the biomass was washed with distilled water to remove any media components. Later, $25 \mathrm{~g}$ of the fungal mycelium (wet weight) was suspended in $100 \mathrm{~mL}$ of Milli-Q water and incubated at $25 \pm 2{ }^{\circ} \mathrm{C}$ on a rotary shaker at $150 \mathrm{rpm}$ for $72 \mathrm{~h}$. The fungal mycelium was filtered and the cell-free filtrate was collected for subsequent experiments. The culture filtrate of T. harzianum was extracted with ethyl acetate (EtOAc) 3 times with a final 1:1 ratio. The combined organic fraction was dried and evaporated under reduced pressure at $35^{\circ} \mathrm{C}$ and used for analysis of bioactive metabolites by LC-MS/MS.

\subsection{Analysis of Bioactive Metabolites Present in T. harzianum Filtrate by LC-MS/MS}

The chemical constituents from culture filtrate were determined using LC-MS/MS. First, $50 \mathrm{mg}$ of T. harzianum culture filtrate extract was suspended in $2 \mathrm{~mL}$ of methanol and filtered through $0.22 \mu \mathrm{m}$ nylon membrane prior to injection. HPLC was coupled with a Q-TOF mass spectrometer fitted with an ESI source. HPLC column Phenomene x $5 \mu \mathrm{C} 8,(150 \times 2 \mathrm{~mm}$ i.d.) was used for the analysis. The solvents were delivered at a total flow rate of $0.1 \mathrm{~mL} / \mathrm{min}$ and run by isocratic elution. The MS spectra were acquired in the positive ion mode. The temperature of the drying gas (N2) was $350{ }^{\circ} \mathrm{C}$, the gas flow rate was $6 \mathrm{~mL} / \mathrm{min}$ and the nebulizing pressure $\left(\mathrm{N}_{2}\right)$ was25 psi. A $20 \mu \mathrm{L}$ volume of fungal extract was injected onto the analytical column for analysis. The mass fragmentations were identified by using a spectrum database for organic compounds. The analytical LC/MS experiment was performed using a TSQ Quantum Access MAX Triple-Stage Quadrupole Mass Spectrometer. Waters Mass Lynx and Target Lynx software were used for data acquisition and data processing, respectively. The MS analysis was performed using ESI in the positive mode. The MS parameters were curtain gas 10, gas1 20 and gas 20, needle voltage $5000 \mathrm{~V}$ and declustering potential $100 \mathrm{~V}$. TOF was operated between 50 and $1500 \mathrm{~m} / z$ with low mass resolution of 4.7 and high mass resolution of 15 .

\subsection{Biosynthesis of Silver Nanoparticles (AgNPs)}

For the synthesis of AgNPs, the culture filtrate was mixed with $1 \mathrm{mM}$ silver nitrate solution $\left(\mathrm{AgNO}_{3}\right)$ in the ratio of $1: 9(\mathrm{v} / \mathrm{v})$, and the reaction mixture was incubated at $25^{\circ} \mathrm{C}$ and $100 \mathrm{rpm}$ overnight (to avoid photoactivation of $\mathrm{AgNO}_{3}$ ). The change in color of the solution from yellowish-brown to dark brown indicated the reduction of silver nitrate to silver ions. The dark brown solution was subjected to centrifugation at 15,000 rpm for $25 \mathrm{~min}$, the supernatant was discarded and the pellet was washed 5-6 times with sterile distilled water. The AgNPs obtained were dried at $60{ }^{\circ} \mathrm{C}$ for $24 \mathrm{~h}$ and then used for characterization studies. The filtrate without $\mathrm{AgNO}_{3}$ was used as negative control.

\subsection{Characterization of Synthesized Silver Nanoparticles (AgNPs)}

The maximum absorbance of AgNPs obtained was determined by spectral scan in the range between 200 and $800 \mathrm{~nm}$ using a UV-Vis spectrophotometer (Hitachi, U2800). The reduction of pure silver ions synthesized by fungal filtrate was observed by measuring the UV-Vis spectrum of the reaction mixture. The analysis of AgNPs with Fourier transform infrared spectrometry (FT-IR) was performed by scanning in the spectral range $400-4000 \mathrm{~cm}^{-1}$ at a resolution of $4 \mathrm{~cm}^{-1}$ (Perkin Elmer Spectrum 1000). FT-IR spectra in solid phase were recorded as potassium bromide pellets to detect the possible functional groups in the fungal filtrate responsible for the reduction of ions and the capping agents responsible for the stability of nanoparticles. The energy-dispersive spectroscopy (EDS) assay was conducted using $0.2 \mathrm{~g}$ of $\mathrm{AgNO}_{3}$ crystals to detect the presence of silver ions in the samples (Hitachi Noran System 7, USA). The DLS analysis was conducted to check the size and dispersal pattern of biosynthesized AgNPs existing in solution (Microtrac 
/FLEX 11.0.0.2). Scanning electron microscopy (SEM) analysis was carried out using a tiny film of AgNPs placed on carbon-coated copper grid film and dried using a mercury lamp for $5 \mathrm{~min}$. The morphological structure obtained from the biosynthesized AgNPs was determined (Hitachi, S-3400N, Tokyo, Japan). The X-ray powder diffraction (XRD) patterns of synthesized AgNPs were detected using a X-ray powder diffractometer (Rigaku Desktop Miniflex II) with $\mathrm{Cu} \mathrm{K} \alpha$ radiation $\left(\lambda=1.5406 \mathrm{~A}^{\circ}\right)$ as the energy source. The diffracted intensities were recorded at $2 \theta$ angles from $10-80^{\circ}$. The location of the highest peak was compared with standard libraries to detect crystal-like phases. The size and nature of biosynthesized nanoparticles were obtained by XRD. The size of the NPs was determined by the Debye-Sherrer equation given as follows:

$$
\mathrm{D}=\mathrm{K} \lambda / \beta \cos \theta
$$

where $\lambda$ is the $X$-ray wavelength, $D$ is the particle size $(\mathrm{nm}), \beta$ is the full line width at half maximum (FWHM) elevation of the important peak, $\mathrm{K}$ is the shape factor and $\theta$ is the refractive (Bragg) angle.

\subsection{Determination of Antioxidant Activities}

\subsubsection{2,2-Diphenyl-1-picryl-hydrazyl-hydrate (DPPH) Scavenging Activity Assay}

The biosynthesized AgNPs and the culture filtrate were used to assess the antioxidant property by DPPH radical scavenging assay [25]. First, $1.5 \mathrm{~mL}$ of freshly prepared DPPH (4 mg of DPPH in $100 \mathrm{~mL}$ of $95 \%$ ethyl alcohol) was added to $1.5 \mathrm{~mL}$ of culture filtrate and AgNPs samples $(0.20-1.0 \mathrm{mg} / \mathrm{mL})$. After incubation at room temperature in the dark for $30 \mathrm{~min}$, reduction of DPPH was determined spectrophotometrically at $517 \mathrm{~nm}$ against the blank (1.5 mL of DPPH solution and $1 \mathrm{~mL}$ of $95 \%$ ethanol); gallic acid was used as standard $(0.2-1.0 \mathrm{mg} / \mathrm{mL}$ in $95 \%$ ethyl alcohol). The blank consisted of $1.5 \mathrm{~mL}$ of DPPH solution containing the filtrate. The experiments were repeated thrice. The percent activity and $\mathrm{IC}_{50}$ (concentration of sample needed to inhibit 50\% DPPH) were determined.

$$
\text { Percent activity }(\%)=[(\mathrm{Ac}-\mathrm{As}) / \mathrm{Ac}] \times 100
$$

where Ac is the absorbance of control or blank and As is the absorbance of the AgNP mixture or standard.

\subsubsection{Ferric Reducing Antioxidant Power (FRAP) Assay}

The antioxidant potential of AgNPs and the culture filtrate was analyzed by ferric reducing antioxidant power (FRAP) assay [26]. The FRAP reagent $(4.5 \mathrm{~mL})$ was prepared by mixing $2.5 \mathrm{~mL}$ of TPTZ (2,4,6-tripyridyl-striazine) solution $(10 \mathrm{mM} \mathrm{TPTZ} \mathrm{in} 40 \mathrm{mM} \mathrm{HCl})$ and $20 \mathrm{mM} \mathrm{FeCl}_{3}$ in $25 \mathrm{~mL}$ of acetate buffer $(0.3 \mathrm{M}, \mathrm{pH} 3.6)$ with $0.5 \mathrm{~mL}$ of test samples at different concentrations $(0.2-1.0 \mathrm{mg} / \mathrm{mL})$. Deionized water and ethanol were used as blank. The reaction mixture was incubated at $37^{\circ} \mathrm{C}$ for $30 \mathrm{~min}$, and the absorbance was recorded at $593 \mathrm{~nm}$. A dark blue color formed as $\mathrm{Fe}^{3+}-\mathrm{TPTZ}$ complex was reduced to $\mathrm{Fe}^{2+}-\mathrm{TPTZ}$. Freshly prepared aqueous ascorbic acid solution $(0.2-1.0 \mathrm{mg} / \mathrm{mL})$ was used as standard.

\subsection{Determination of Antibacterial Activity by Disc Diffusion Method}

\subsubsection{Microbial Cultures Used for Antibacterial Activity}

Escherichia coli (NCIM-2256), Staphylococcus aureus (NCIM-2079) and Bacillus subtilis (NCIM-2724) obtained from the National Collection of Industrial Microorganisms (NCIM), Pune, India, were used in this study. Ralstonia solanacearum (RS5-KF924743) bacterium was isolated from rhizospheric soil.

\subsubsection{Antibacterial Activity of Synthesized AgNPs}

The antibacterial efficacy of the synthesized AgNPs was evaluated by disc diffusion method using two Gram-positive bacteria, namely S. aureus and B. subtilis, and two Gramnegative bacteria, namely E. coli and $R$. solanacearum. Briefly, the bacterial cultures were 
inoculated into $5 \mathrm{~mL}$ of sterile nutrient broth and incubated at $37^{\circ} \mathrm{C}$ until the turbidity matched the $0.5 \mathrm{McF}$ arland standard. The bacterial broth was swabbed onto sterile Mueller Hinton agar (MHA) plates to obtain lawn culture. The sterile discs $(6 \mathrm{~mm})$ soaked overnight in $25 \mu \mathrm{L}$ of AgNPs $(0.25 \mathrm{mg} / \mathrm{mL})$ were placed at equidistance on MHA plates and allowed to diffuse at $4{ }^{\circ} \mathrm{C}$ for $4-5 \mathrm{~h}$. Streptomycin $(25 \mu \mathrm{g} / \mathrm{disc})$ was used as the positive control and the culture filtrate served as a negative control. The plates were then incubated at $37^{\circ} \mathrm{C}$ overnight and the zone of inhibition was measured. The experiments were repeated thrice and mean values were recorded.

\subsection{Minimum Inhibitory Concentration (MIC)}

The MIC of AgNPs was determined by the dilution plate method. Various dilutions of AgNPs were prepared, ranging from 4096 to $8 \mu \mathrm{g} / \mathrm{mL}$. One hundred microliters of nutrient broth was added to the micro wells of an ELISA plate, and an equal volume of AgNPs ranging from 4096 to $8 \mu \mathrm{g} / \mathrm{mL}$ was added to each well. Ten microliters of bacteria $\left(1 \times 10^{5} \mathrm{CFU} / \mathrm{mL}\right)$ was added to each well before incubation at $37^{\circ} \mathrm{C}$ for $24 \mathrm{~h}$, and absorbance was measured at $620 \mathrm{~nm}$ using an ELISA plate reader. Streptomycin was used as the positive control. The MIC was also observed by the addition of $10 \mu \mathrm{L}(2 \mathrm{mg} / \mathrm{mL})$ of 2,3,5-triphenyl tetrazolium chloride (TZC), incubated at room temperature for $30 \mathrm{~min}$. The lowest concentration of AgNPs that significantly inhibited the growth of bacteria in comparison with the positive control was recorded as the MIC [27]. The experiments were repeated thrice and mean values were recorded.

\subsection{Fluorescence Microscopy and Scanning Electron Microscopy (SEM) Analysis}

The growth of S. aureus (Gram-positive bacteria) and R. solanacearum (Gram-negative bacteria) was inhibited by AgNPs at a concentration of $0.25 \mathrm{mg} / \mathrm{mL}$, as determined by the disc diffusion assay. Hence, $0.25 \mathrm{mg} / \mathrm{mL}$ of AgNPs was used for the detection of both dead and live cells by fluorescent microscopy. S. aureus and $R$. solanacearum were treated with AgNPs $(0.25 \mathrm{mg} / \mathrm{mL})$ and incubated for $24 \mathrm{~h}$; then, dyes acridine orange $(1 \mu \mathrm{L})$ and ethidium bromide $(1 \mu \mathrm{L})$ were added before further incubation in dark condition for 10-15 min. Acridine orange invades bacterial cells and stains the nuclei green, whereas ethidium bromide invades the cell-membrane-disrupted bacteria and stains the nuclei orange [28]. Ten microliters of bacteria culture treated with fluorescent stains was placed on a slide to observe the stained nuclei under fluorescence microscope at $40 \times$ magnification. The morphological features of treated bacterial cells were further assessed by SEM.

\section{Results}

\subsection{Analysis of Bioactive Metabolites from Fungal Filtrate by LC-MS/MS Method}

The HPLC chromatogram showed several minor peaks at various retention times ranging from 0.20 to $2.20 \mathrm{~min}$. The prominent peak with an area of 246,184.42 was obtained at the retention time of $1.33 \mathrm{~min}$ (Figure 1A). The LC-MS/MS spectra of the filtrate showed the presence of five different compounds with varied mass obtained at different retention times (Figure 1B-D). The compounds were tentatively identified based on the mass obtained from LC-MS/MS by comparison with the previously reported compounds documented in databases. The compounds were identified as 1-benzoyl-3-[(S)- $((2 S, 4 R, 8 R)-$ 8-ethylquinuclidin-2-yl](6-methoxyquinolin-4-yl)methyl)thiourea $(\mathrm{m} / \mathrm{z}$ 489.2323), puerarin $(m / z$ 416.2064), genistein $(m / z$ 432.2986), isotalatizidine $(m / z$ 407.2975) and ginsenoside $(m / z$ 800.5387) (Table 1). These compounds were previously reported to exhibit antimicrobial, antibacterial, antioxidant and anticancer properties.

\subsection{Characterization of Silver Nanoparticles (AgNPs)}

The green-synthesized AgNPs were characterized by ultraviolet-visible spectrophotometry, Fourier transform infrared spectrometry (FT-IR), energy-dispersive spectroscopy (EDS), dynamic light scattering (DLS), X-ray powder diffraction (XRD) and scanning electron microscopy (SEM). 


\subsubsection{UV-Visible Spectroscopy Analysis of AgNPs}

The addition of filtrate to silver nitrate $\left(\mathrm{AgNO}_{3}\right)$ resulted in a color change from pale yellowish-brown to reddish-brown due to the formation of silver nanoparticles (AgNPs). The change in color occurred due to the excitation of surface plasmon resonance (SPR) from AgNPs. The SPR of AgNPs formed a peak centered near $438 \mathrm{~nm}$ (Figure 2). The absorbance of AgNPs solution was taken initially when the color of the solution was pale yellowish-brown, and it was also taken after the color of the solution turned reddish-brown. The potential synthesis mechanism included the reduction of silver ions from toxic silver cation $\left(\mathrm{Ag}^{+}\right)$to stable $\mathrm{Ag}^{\circ}$ due to the capping agents that existed in the filtrate.

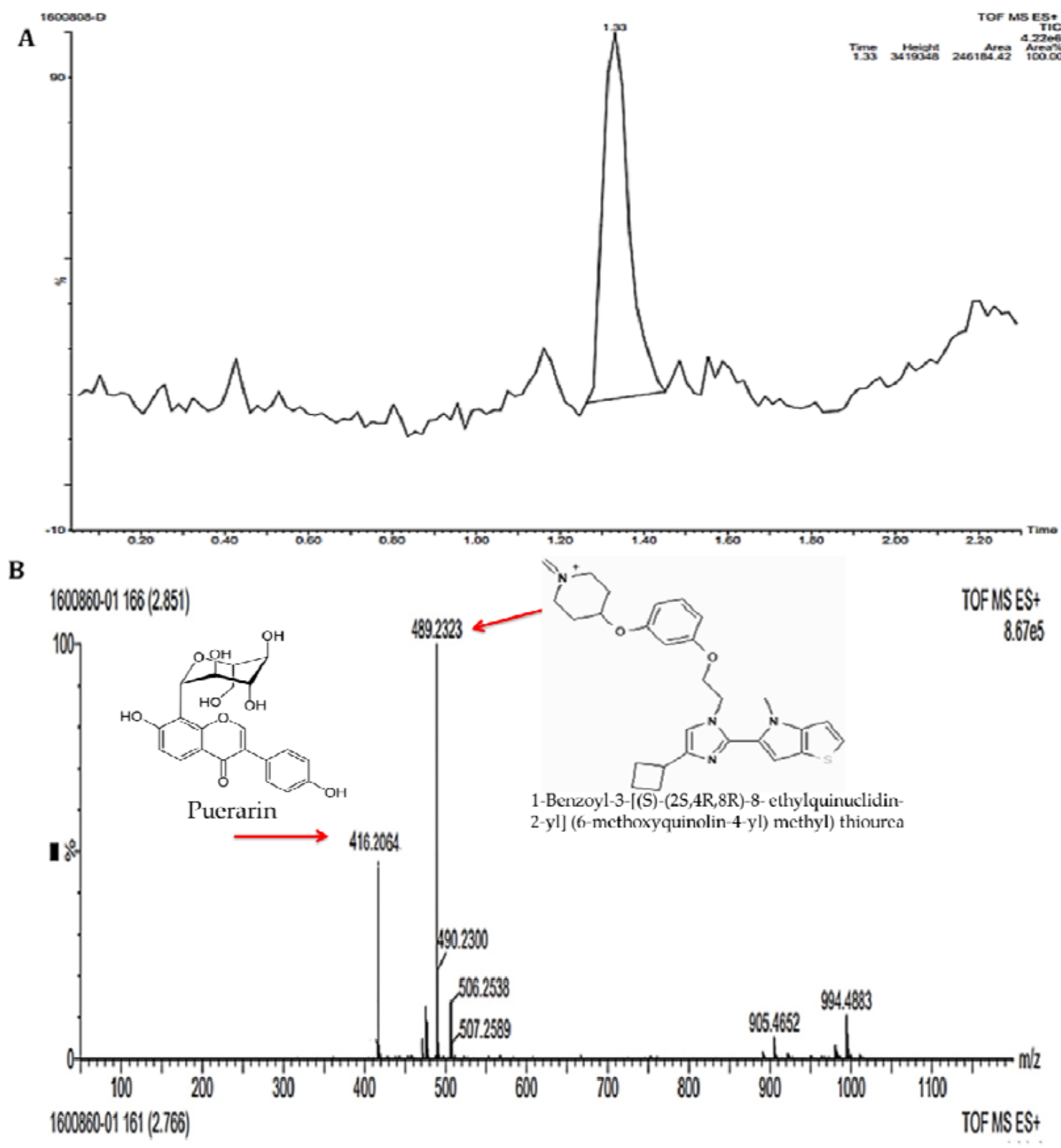

Figure 1. Cont. 


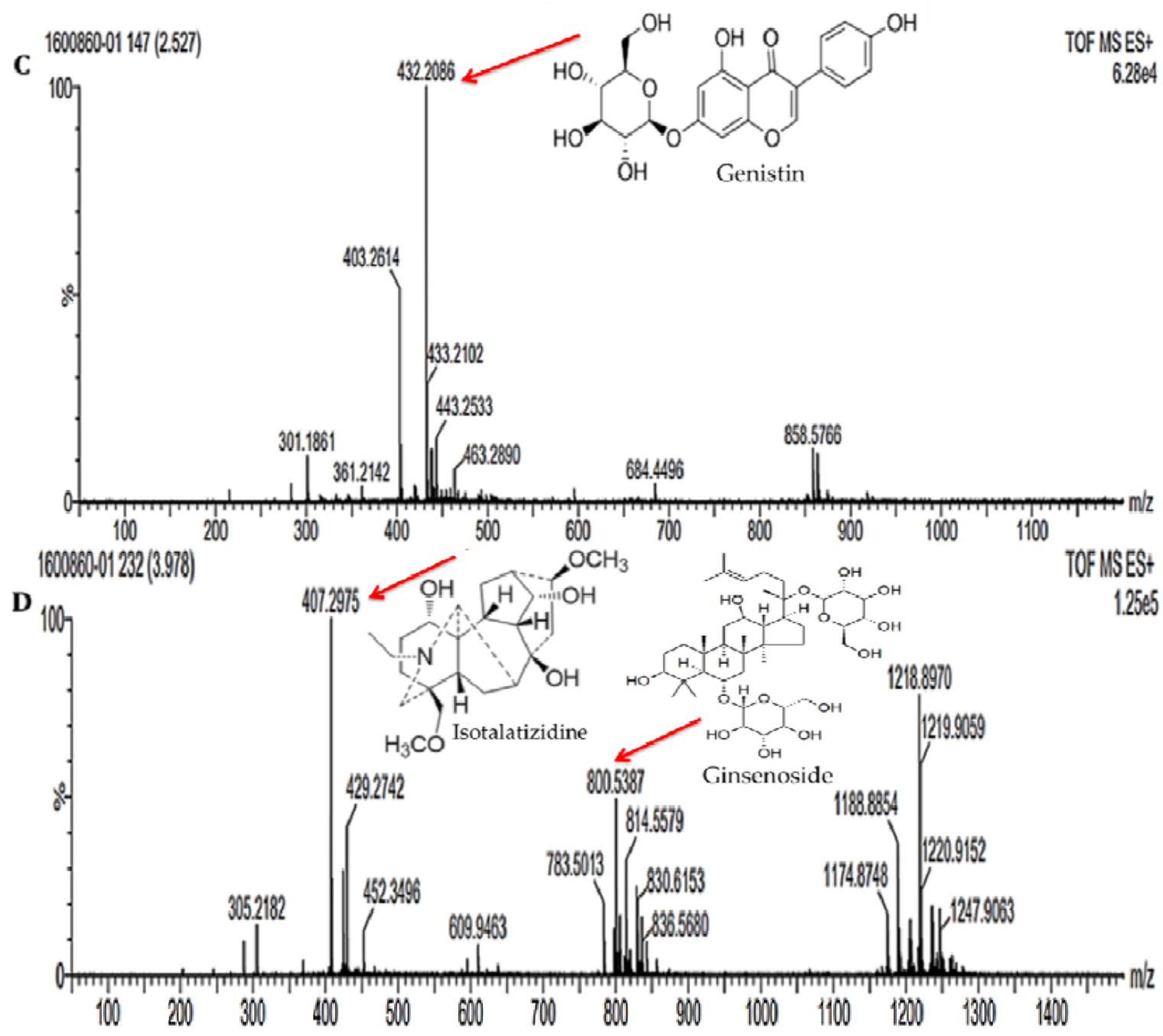

Figure 1. (A) HPLC chromatograms of the Trichoderma harzianum filtrate. (B) LC-MS/MS spectra of antibacterial compounds from Trichoderma harzianum filtrate: 1-benzoyl-3-[(S)-((2S,4R,8R)-8-ethylquinuclidin-2-yl](6-methoxyquinolin-4-yl)methyl) thiourea $(m / z$ 489.2323) and puerarin ( $m / z$ 416.2064). (C,D) LC-MS/MS spectra of antimicrobial compounds from Trichoderma harzianum filtrate: (C) genistin ( $\mathrm{m} / \mathrm{z}$ 432.2086); (D) isotalatizidine $(\mathrm{m} / \mathrm{z}$ 407.2975) and ginsenoside $(\mathrm{m} / \mathrm{z} 800.5387)$.

Table 1. Antibacterial compounds identified in Trichoderma harzianum filtrate using LC-MS/MS.

\begin{tabular}{|c|c|c|c|c|c|c|c|}
\hline S1. No. & $\begin{array}{c}m / z \\
\text { Obtained }\end{array}$ & Actual Mass & Error & $\begin{array}{c}\text { Molecular } \\
\text { Formula }\end{array}$ & Tentative Identification & $\begin{array}{l}\text { Biological } \\
\text { Activity }\end{array}$ & References \\
\hline 1. & 489.2323 & 489.2323 & 0.0 & $\mathrm{C}_{28} \mathrm{H}_{33} \mathrm{~N}_{4} \mathrm{O}_{2} \mathrm{~S}$ & $\begin{array}{c}\text { 1-Benzoyl-3-[(S)- } \\
((2 S, 4 R, 8 R)-8- \\
\text { ethylquinuclidin-2-yl](6- } \\
\text { methoxyquinolin-4- } \\
\text { yl)methyl)thiourea }\end{array}$ & $\begin{array}{c}\text { Antibacterial } \\
\text { activities }\end{array}$ & [29] \\
\hline 2. & 416.2064 & 416.382 & 0.1756 & $\mathrm{C}_{21} \mathrm{H}_{20} \mathrm{O}_{9}$ & Puerarin & $\begin{array}{l}\text { Antimicrobial and } \\
\text { antioxidant } \\
\text { activities }\end{array}$ & {$[30,31]$} \\
\hline 3 & 432.2086 & 432.37 & 0.1614 & $\mathrm{C}_{21} \mathrm{H}_{20} \mathrm{O}_{10}$ & Genistein & $\begin{array}{l}\text { Antimicrobial and } \\
\text { antioxidant } \\
\text { activities }\end{array}$ & [32] \\
\hline 4 & 407.2975 & 407.5 & 0.2025 & $\mathrm{C}_{23} \mathrm{H}_{37} \mathrm{NO}_{5}$ & Isotalatizidine & $\begin{array}{l}\text { Antibacterial } \\
\text { activities }\end{array}$ & [33] \\
\hline 5. & 800.5387 & 801.01 & 0.4713 & $\mathrm{C}_{42} \mathrm{H}_{72} \mathrm{O}_{14}$ & Ginsenoside & $\begin{array}{l}\text { Antimicrobial } \\
\text { activities }\end{array}$ & {$[34]$} \\
\hline
\end{tabular}




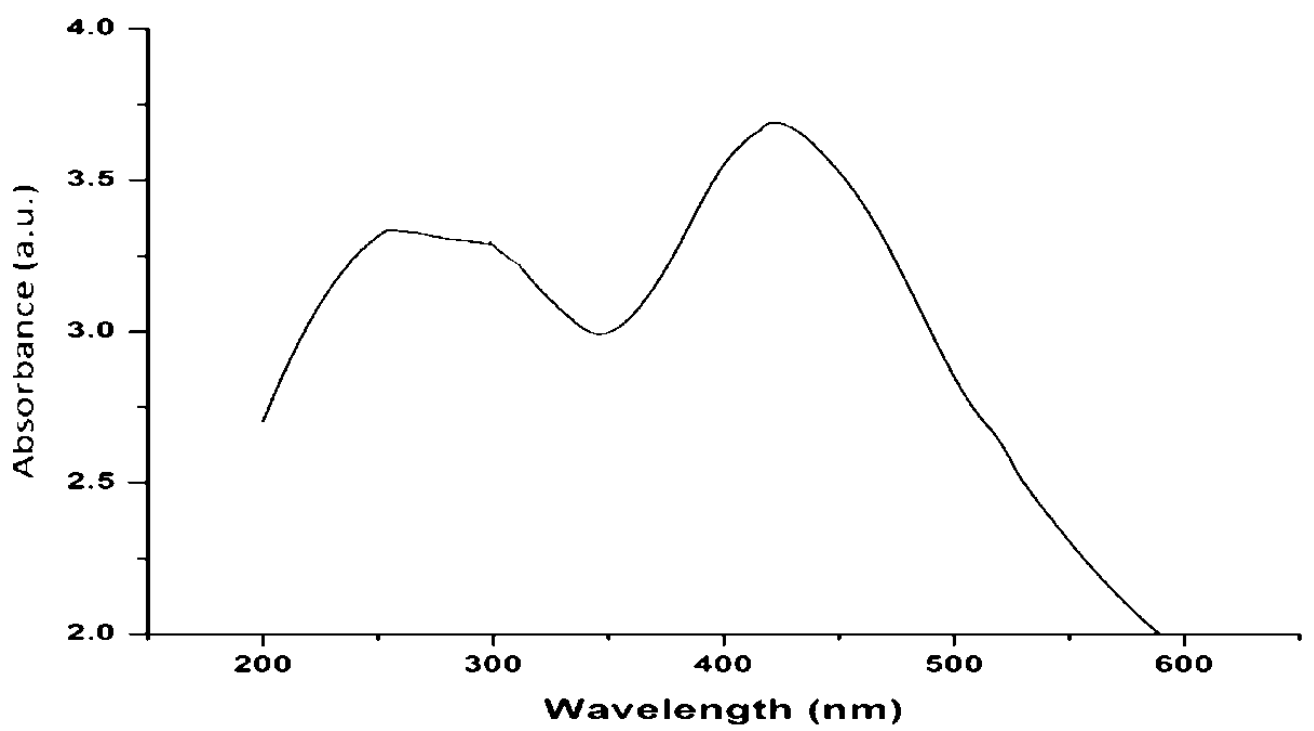

Figure 2. UV-visible spectra of silver nanoparticles synthesized using Trichoderma harzianum filtrate.

\subsubsection{Energy Dispersive Spectroscopy (EDS) Analysis of AgNPs}

Energy dispersive spectroscopy (EDS) analysis confirmed the presence of AgNPs synthesized from filtrate. This analysis revealed the presence of a maximum amount of AgNPs (58.75\%), followed by carbon, oxygen, chlorine, etc. The metallic AgNPs generally display an optical absorption peak at $3 \mathrm{keV}$ because of surface plasmon resonance (Figure 3; Table 2).

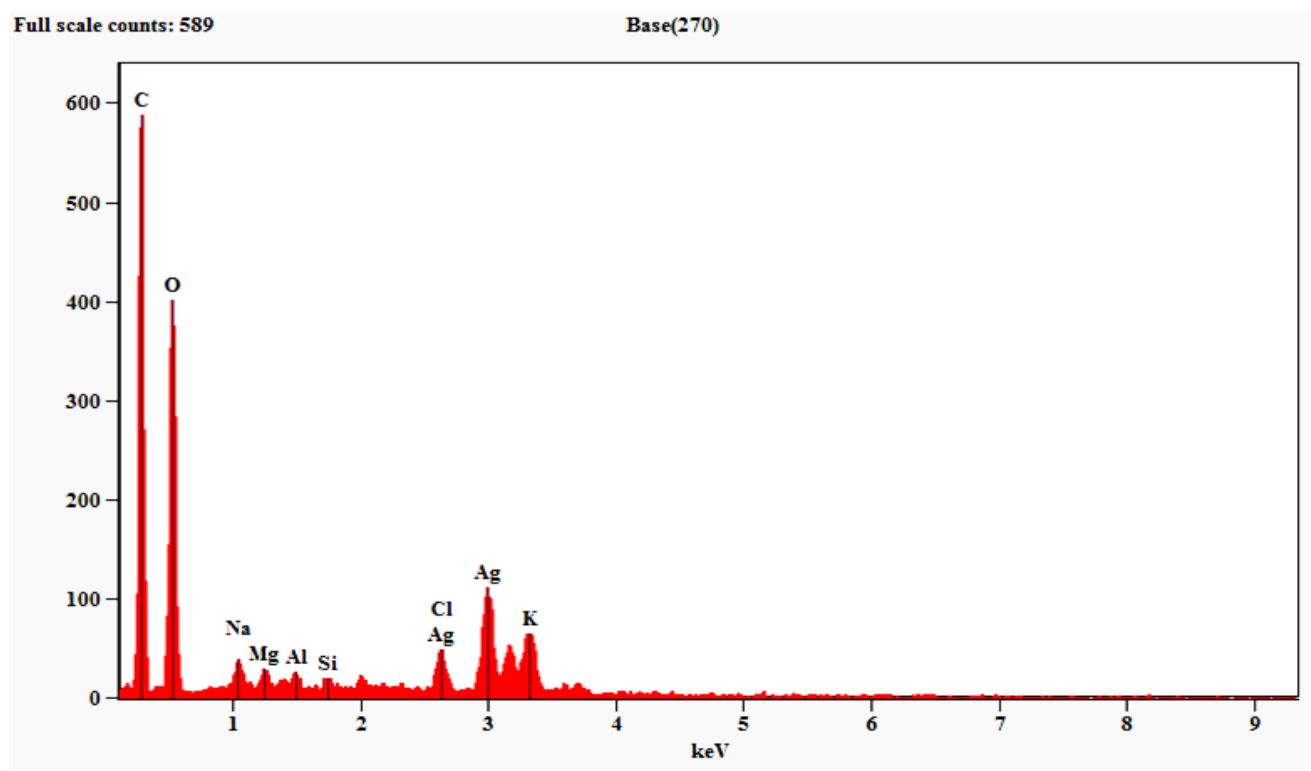

Figure 3. EDS spectra of silver nanoparticles synthesized using Trichoderma harzianum filtrate.

\subsubsection{Dynamic Light Scattering Analysis of AgNPs}

The DLS study was conducted in order to detect the particle size distribution of AgNPs synthesized from filtrate (Figure 4). The size of biosynthesized AgNPs was recorded within a range of 14.64 to $23.52 \mathrm{~nm}$ in diameter. The average size of the AgNPs was $21.49 \mathrm{~nm}$. 
Table 2. Percentage by weight of metallic elements present in silver nanoparticles from T. harzianum filtrate.

\begin{tabular}{cccc}
\hline Element Line & Weight (\%) & Weight \% (Error) & Atom (\%) \\
\hline C K & 0.00 & - & 0.00 \\
O K & 0.00 & - & 0.00 \\
Na K & 12.34 & \pm 1.20 & 27.73 \\
Mg K & 3.91 & \pm 0.72 & 8.32 \\
Al K & 3.01 & \pm 0.57 & 5.77 \\
Cl K & 7.54 & \pm 1.07 & 10.99 \\
Cl L & - & - & - \\
K K & 14.43 & \pm 0.79 & 19.06 \\
K L & - & - & - \\
Ag L & 58.75 & \pm 4.45 & 28.13 \\
Ag M & - & - & - \\
Total & 100.00 & & 100.00 \\
\hline
\end{tabular}

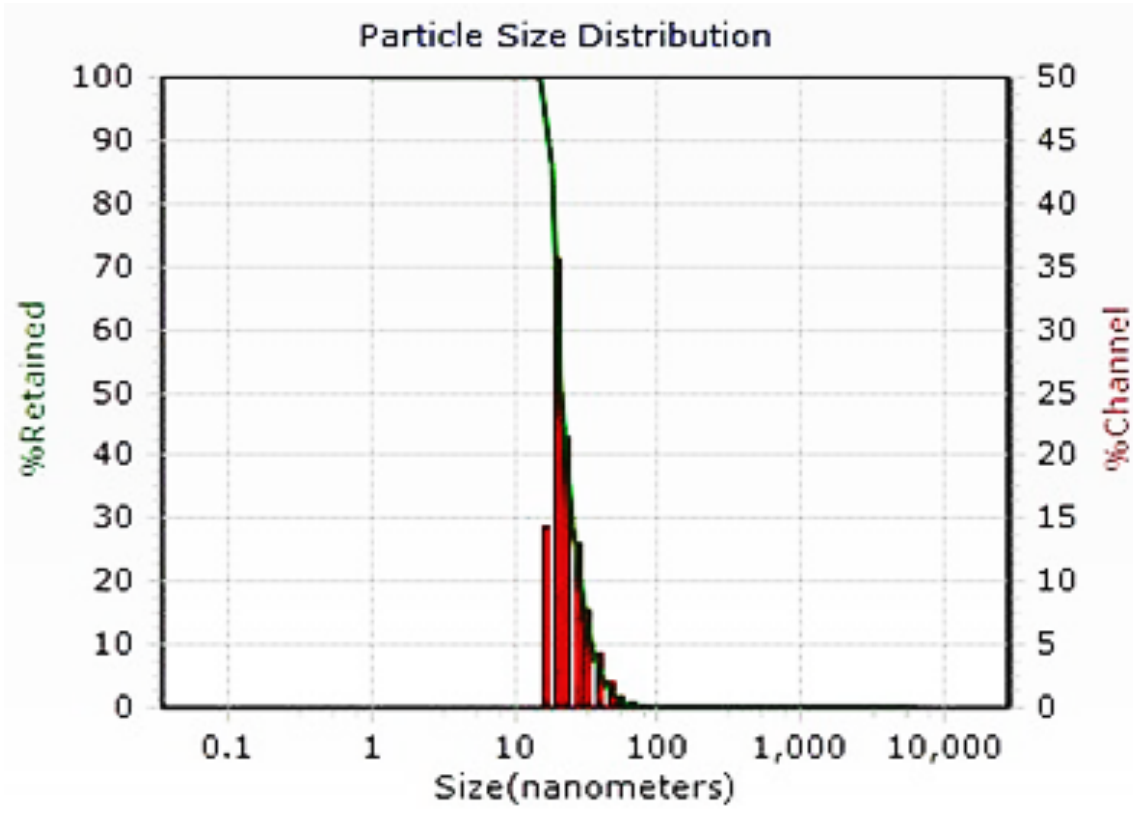

Figure 4. DLS analysis of silver nanoparticles synthesized using Trichoderma harzianum filtrate.

\subsubsection{Scanning Electron Microscopy Analysis of AgNPs}

The size of biosynthesized AgNPs was clearly observed by SEM study and was measured to be $72 \mathrm{~nm}$ (Figure 5). The NPs were found to be highly crystalline in texture.

\subsubsection{Powder X-ray Diffraction Study of AgNPs}

The powder X-ray diffraction pattern of biosynthesized AgNPs was documented using a Bruker D8 Advance $X$-ray diffractometer employing $\mathrm{Cu} \mathrm{K} \alpha$ radiation $(\lambda=1.5406 \AA)$, $40 \mathrm{kV}$ to $40 \mathrm{~mA}, 2 \theta / \theta$ scanning method. The information was collected for a $2 \theta$ range of $10-80^{\circ}$ with a stage of $0.020^{\circ}$. The diffraction data (Figure 6) were compared with standard JCPDS, silver file No. 04-0783. The XRD patterns show peaks of AgNPs at 32.3, 38, 46 and $77^{\circ}$ corresponding to (110), (111), (200) and (311) planes of AgNPs. The XRD study confirmed that the particles were AgNPs with face-centered cubic crystal structures. The peak in the diffraction pattern at $27^{\circ}$ could be due to bioorganic impurities. 


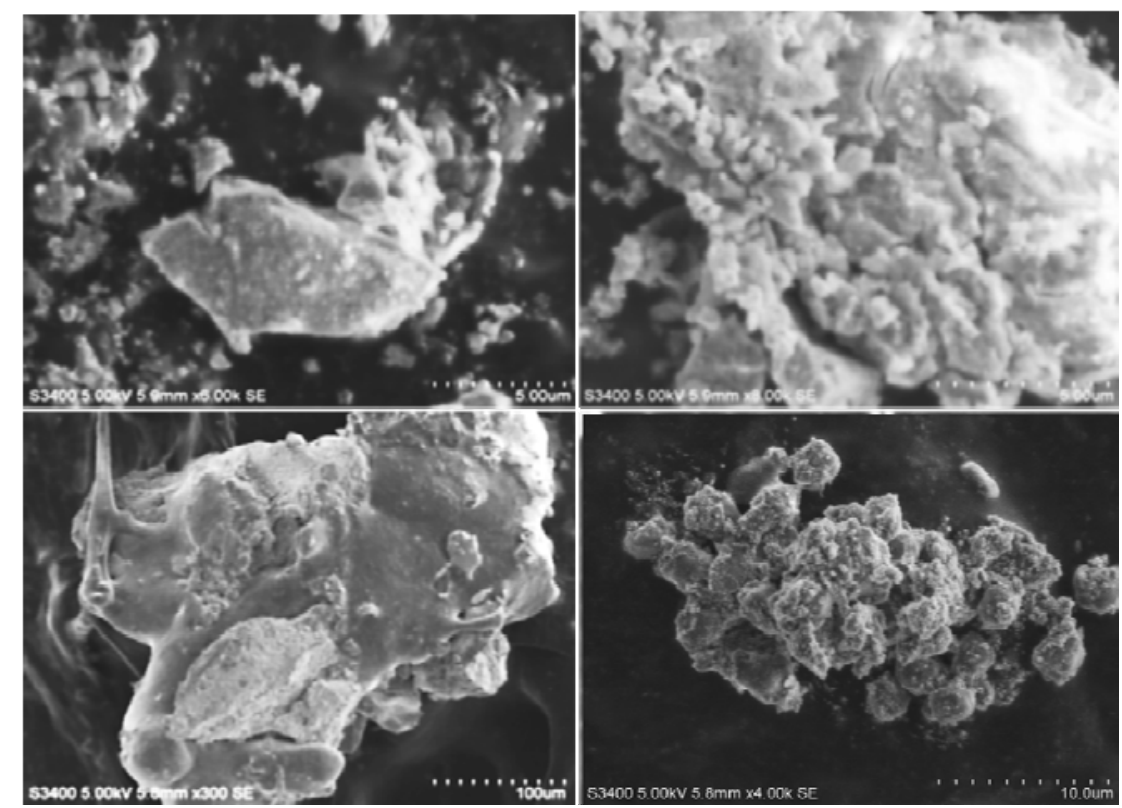

Figure 5. Scanning electron microscopy analysis of silver nanoparticles synthesized using Trichoderma harzianum filtrate.

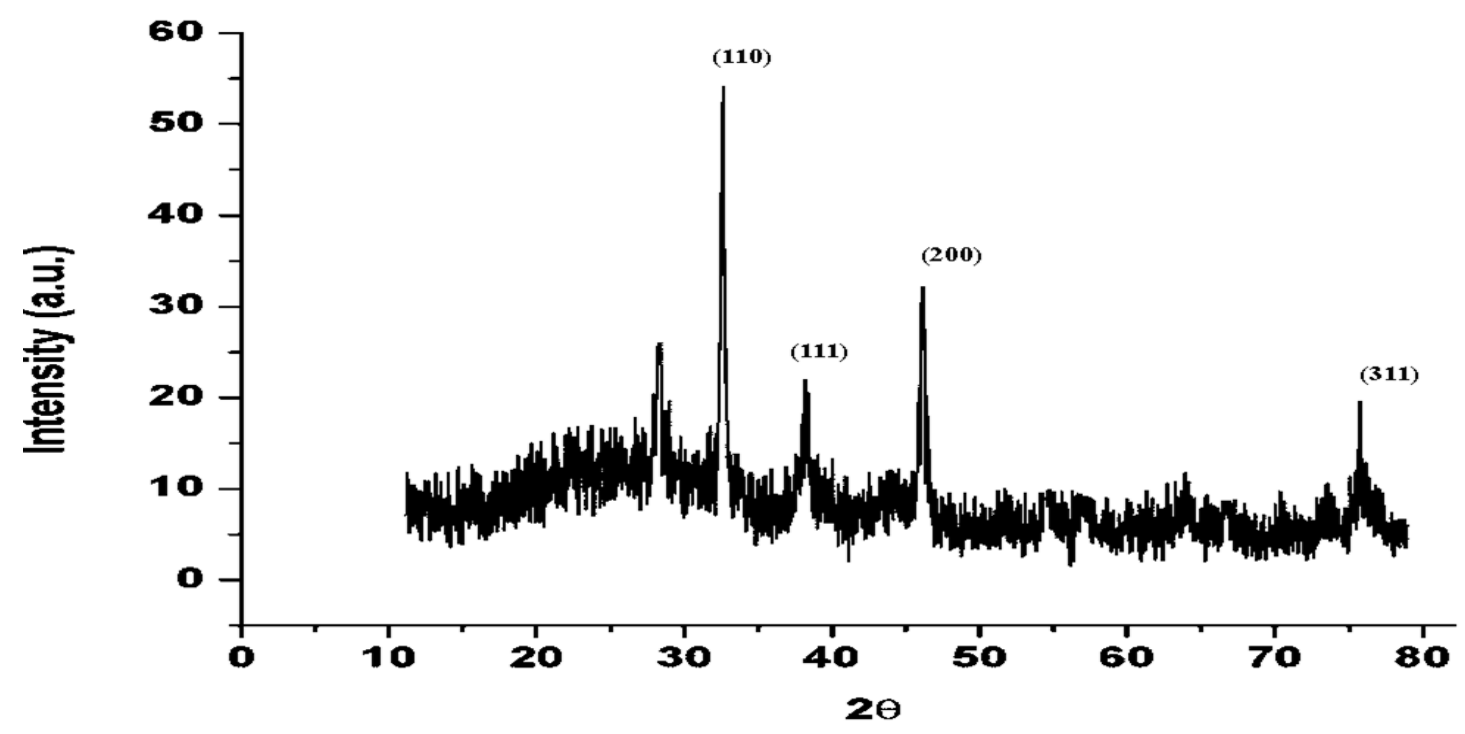

Figure 6. XRD analysis of silver nanoparticles synthesized using Trichoderma harzianum filtrate.

\subsubsection{Fourier Transform Infrared Spectroscopy Analysis of AgNPs}

The FT-IR analysis of biosynthesized AgNPs displayed the presence of a strong peak of aromatic and metal oxide, which indicated that the aromatic secondary metabolites could have been reduced during synthesis and caused stretching at $2980 \mathrm{~cm}^{-1}$; the stretching of alcoholic functional group (O-H stretching) also completely disappeared. The development of metal oxide was also noticed; stretching at $399.26 \mathrm{~cm}^{-1}$ indicated the presence of silver oxide (Figure 7). 


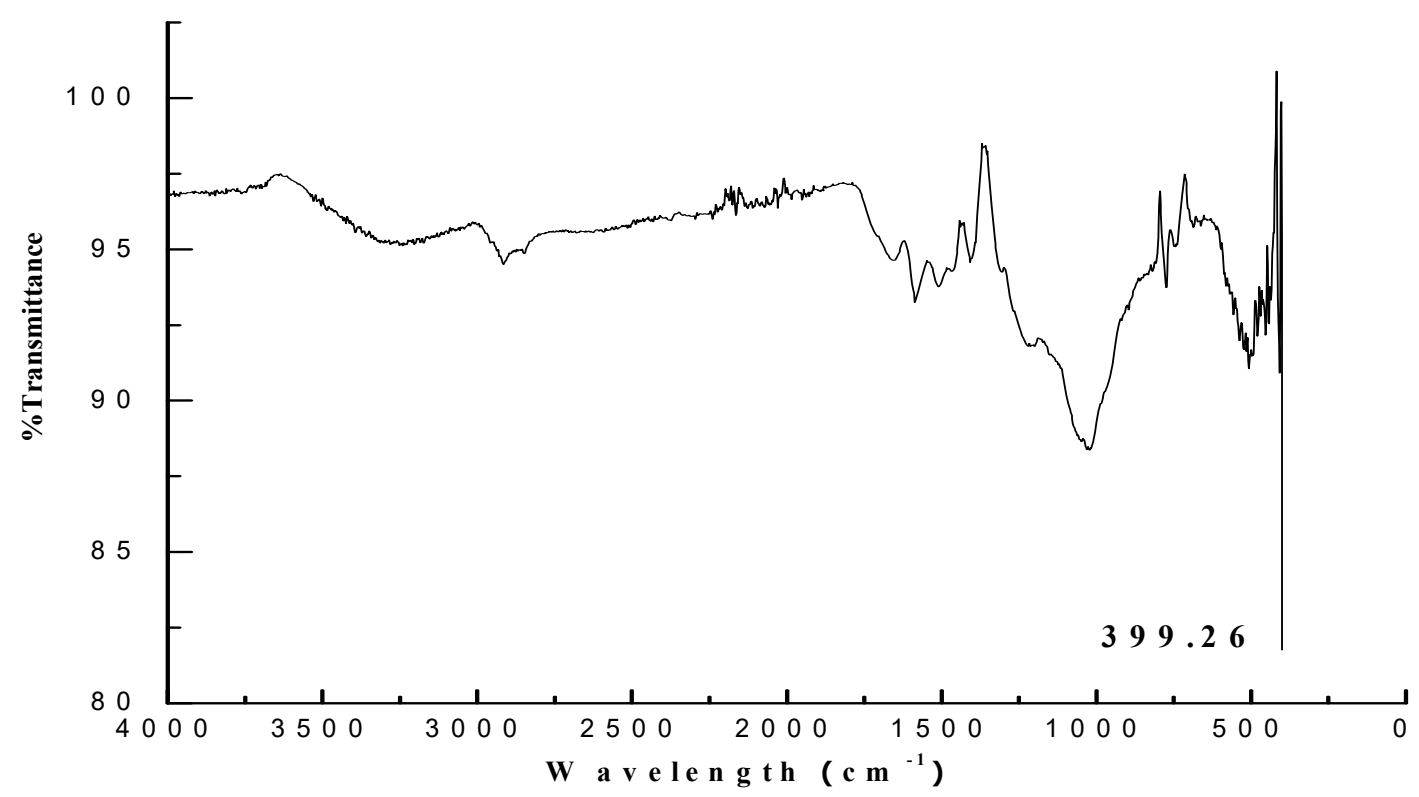

Figure 7. FT-IR spectra of silver nanoparticles synthesized from Trichoderma harzianum filtrate.

\subsection{Antioxidant Activities}

\subsubsection{DPPH Scavenging Activity of AgNPs}

The percent DPPH radical scavenging activity of biosynthesized AgNPs of different concentrations $(0.2-1.0 \mathrm{mg} / \mathrm{mL})$ and filtrate in comparison with gallic acid as standard ranged from 38.6 to $64.93 \%$ (Figure 8A). The DPPH scavenging activity of the synthesized AgNPs was detected based on the change in color from violet to yellow due to the formation of diphenyl picryl hydrazine. The gallic acid (standard) exhibited maximum reducing power, with a scavenging efficacy of $83.3 \%$ at $1 \mathrm{mg} / \mathrm{mL}$. The results of this study indicate that AgNPs exhibited maximum DPPH scavenging activity as compared with the fungal filtrate. The half-maximal inhibitory concentration $\left(\mathrm{IC}_{50}\right)$ values were determined from the graph of regression analysis. The DPPH scavenging activity of AgNPs was recorded with an $\mathrm{IC}_{50}$ value of $0.79 \mathrm{mg} / \mathrm{mL}$, and the $\mathrm{IC}_{50}$ value of gallic acid was $0.23 \mathrm{mg} / \mathrm{mL}$.

\subsubsection{Ferric Reducing Antioxidant Power (FRAP) Assay}

The ferric reducing antioxidant power of AgNPs $(0.2-1.0 \mathrm{mg} / \mathrm{mL})$ and culture filtrate increased with increasing concentration and reached a peak of $66.4 \%$ and $73.98 \%$ at $1 \mathrm{mg} / \mathrm{mL}$, respectively (Figure 8B). The standard, ascorbic acid, exhibited maximum reducing power, with $97.49 \%$ at $1 \mathrm{mg} / \mathrm{mL}$. The results of this study indicated that biosynthesized AgNPs exhibited higher FRAP activity when compared with filtrate.

\subsection{Antibacterial Activity of AgNPs}

The biosynthesized AgNPs exhibited broad-spectrum antibacterial activity, inhibiting all the Gram-positive and Gram-negative bacteria tested. The maximum zone of inhibition was observed against Gram-positive Staphylococcus aureus $(14.6 \mathrm{~mm})$, followed by Bacillus subtilis (13.86 mm). Among the Gram-negative bacteria, inhibition zones of 17.43 and $15.56 \mathrm{~mm}$ were exhibited against $R$. solanacearum and Escherichia coli, respectively (Figure 9; Table 3). 

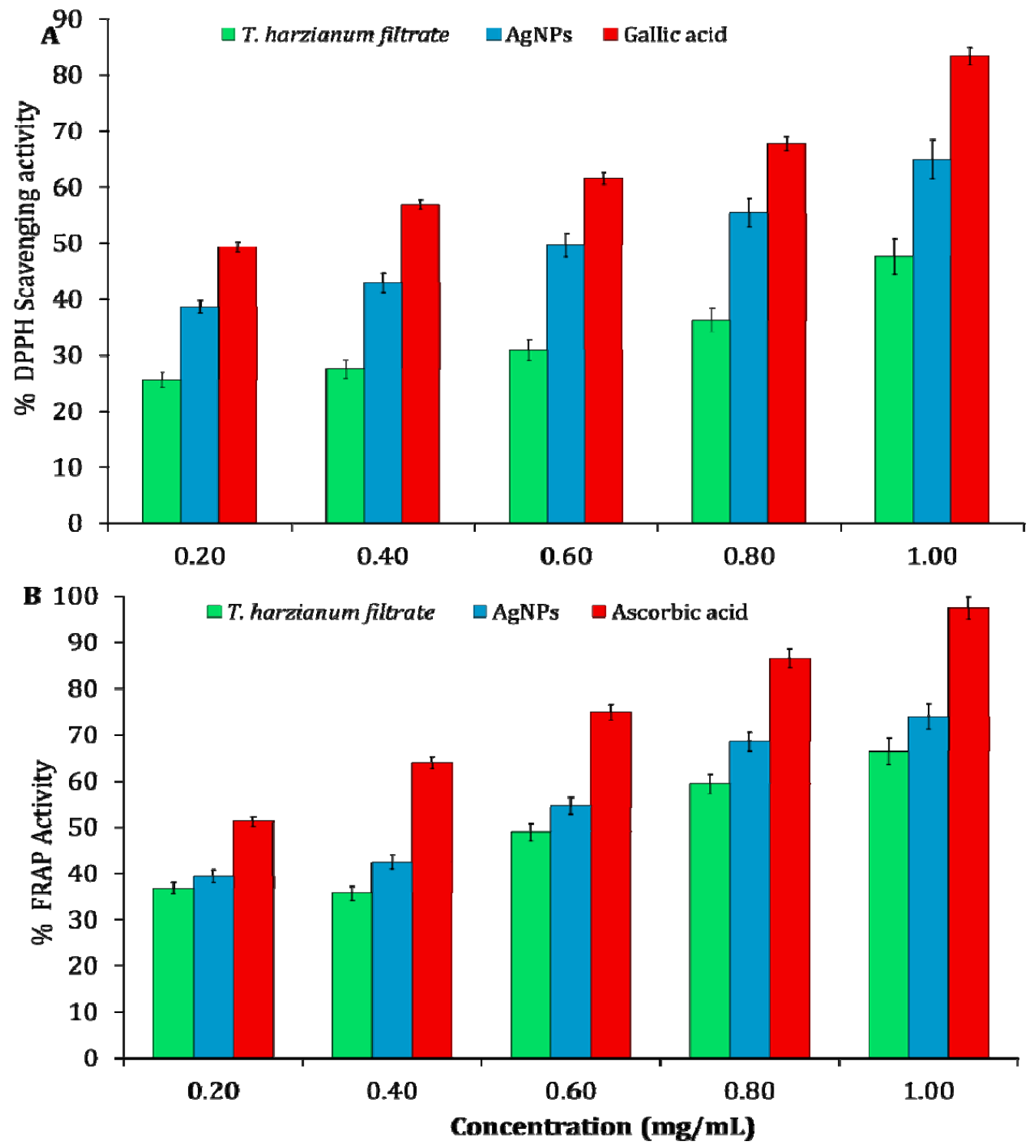

Figure 8. (A) Estimation of DPPH radical scavenging activity and (B) ferric reducing antioxidant power activity from different concentrations of silver nanoparticles synthesized using Trichoderma harzianum filtrate.

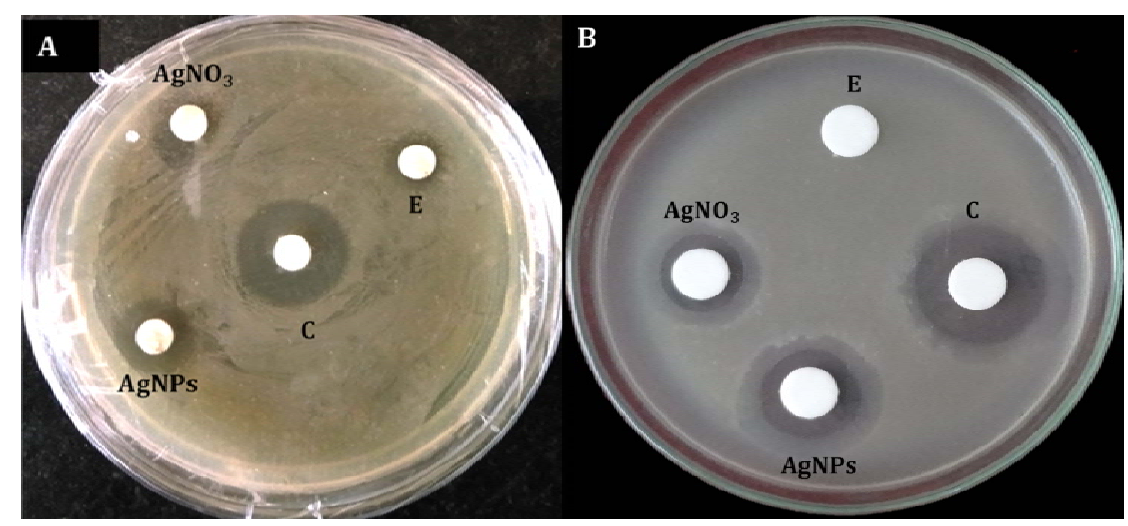

Figure 9. Antibacterial activity of silver nanoparticles synthesized using Trichoderma harzianum filtrate, as determined by disc diffusion method. (A) Staphylococcus aureus (Gram-positive); (B) Ralstonia solanacearum (Gram-negative). C: Positive control (streptomycin); AgNPs: silver nanoparticles; $\mathrm{AgNO}_{3}$ : silver nitrate; $\mathrm{E}$ : negative control (Trichoderma harzianum culture filtrate). 
Table 3. Zone of inhibition of antibacterial activity exhibited by silver nanoparticles (AgNPs) from T. harzianum.

\begin{tabular}{ccccc}
\hline & \multicolumn{4}{c}{ Zone of Inhibition (mm) } \\
\cline { 2 - 5 } Microorganisms & AgNPs & $\begin{array}{c}\text { Silver } \\
\text { Nitrate }\end{array}$ & T. harzianumfiltrate & $\begin{array}{c}\text { Streptomycin } \\
\mathbf{( 2 5} \boldsymbol{\mu g} / \mathbf{d i s c})\end{array}$ \\
\hline & & Antibacterial activity & \\
\hline Staphylococcus aureus & $14.6 \pm 2.33^{\mathrm{bc}}$ & $2.3 \pm 0.23^{\mathrm{a}}$ & $4.3 \pm 0.66^{\mathrm{c}}$ & $16.89 \pm 0.54^{\mathrm{a}}$ \\
Bacillus subtilis & $13.86 \pm 0.57^{\mathrm{a}}$ & $2.9 \pm 0.56^{\mathrm{c}}$ & $4.9 \pm 0.66^{\mathrm{d}}$ & $25.56 \pm 0.78^{\mathrm{c}}$ \\
Escherichia coli & $15.56 \pm 1.67^{\mathrm{d}}$ & $2.7 \pm 0.54^{\mathrm{b}}$ & $2.9 \pm 0.54^{\mathrm{b}}$ & $25.33 \pm 0.6^{\mathrm{b}}$ \\
Ralstonia solanacearum & $17.43 \pm 1.23^{\mathrm{e}}$ & $4.56 \pm 0.89^{\mathrm{de}}$ & $1.0 \pm 0.08^{\mathrm{a}}$ & $20.21 \pm 0.48^{\mathrm{d}}$ \\
\hline
\end{tabular}

The data represent mean \pm SE of replicates $(n=3)$. Data with different superscript letters are significantly different between treatments and control, as determined by Duncan's multiple range test, at $p \leq 0.05$.

\subsection{Minimum Inhibitory Concentration(MIC)}

The MICs of biosynthesized AgNPs against Gram-positive and Gram-negative bacteria were evaluated by the broth microdilution method. The green-synthesized AgNPs exhibited MIC of $256 \mu \mathrm{g} / \mathrm{mL}$ against S. aureus, $128 \mu \mathrm{g} / \mathrm{mL}$ against E. coli, $512 \mu \mathrm{g} / \mathrm{mL}$ against $B$. subtilis and $64 \mu \mathrm{g} / \mathrm{mL}$ against $R$. solanacearum (Table 4 ).

Table 4. Minimum inhibitory concentration of AgNPs from Trichoderma harzianum against bacterial pathogens.

\begin{tabular}{|c|c|c|c|c|c|c|c|c|c|c|c|}
\hline Pathogens & 4096 & 2048 & 1024 & 512 & 256 & 128 & 64 & 32 & 16 & 8 & $\begin{array}{c}\mathrm{MIC} \\
\left(\mu \mathrm{g} \mathrm{mL}^{-1}\right)\end{array}$ \\
\hline S. aureus & - & - & - & - & - & + & + & + & + & + & 256 \\
\hline B. subtilis & - & - & - & - & + & + & + & + & + & + & 512 \\
\hline E. coli & - & - & - & - & - & - & + & + & + & + & 128 \\
\hline R. solanacearum & - & - & - & - & - & - & - & + & + & + & 64 \\
\hline $\begin{array}{c}\text { Streptomycin } \\
\text { (positive control) }\end{array}$ & - & - & - & - & - & - & - & - & - & + & 16 \\
\hline $\begin{array}{l}\text { Culture filtrate } \\
\text { (negative control) }\end{array}$ & - & - & - & + & + & + & + & + & + & + & 1024 \\
\hline
\end{tabular}

Note: - represents no growth of bacterial pathogens; + represents the growth of bacterial pathogens; MIC: minimum inhibitory concentration.

\subsection{Fluorescence Microscopy and Scanning Electron Microscopy Analysis}

The fluorescence microscopy studies confirmed the antibacterial activity of AgNPs against both Gram-positive and Gram-negative bacteria. The bacterial cells without AgNP treatment were used as control, these bacteria showed green color under fluorescence microscope, indicating the presence of live bacterial cells; the bacterial cells treated with AgNPs showed red color under fluorescence microscope, and the shrinkage of bacterial cell walls, non-homologous exterior and collapse were also noticed (Figure 10). The bacterial cells treated with AgNPs were further subjected to SEM analysis to detect the exact morphological changes in the bacteria. The bacterial cells treated with AgNPs exhibited significant noticeable morphological changes, which included the disruption of the bacterial cell wall resulting in leakage of intracellular materials, and bacterial clumps were formed (Figure 11). 

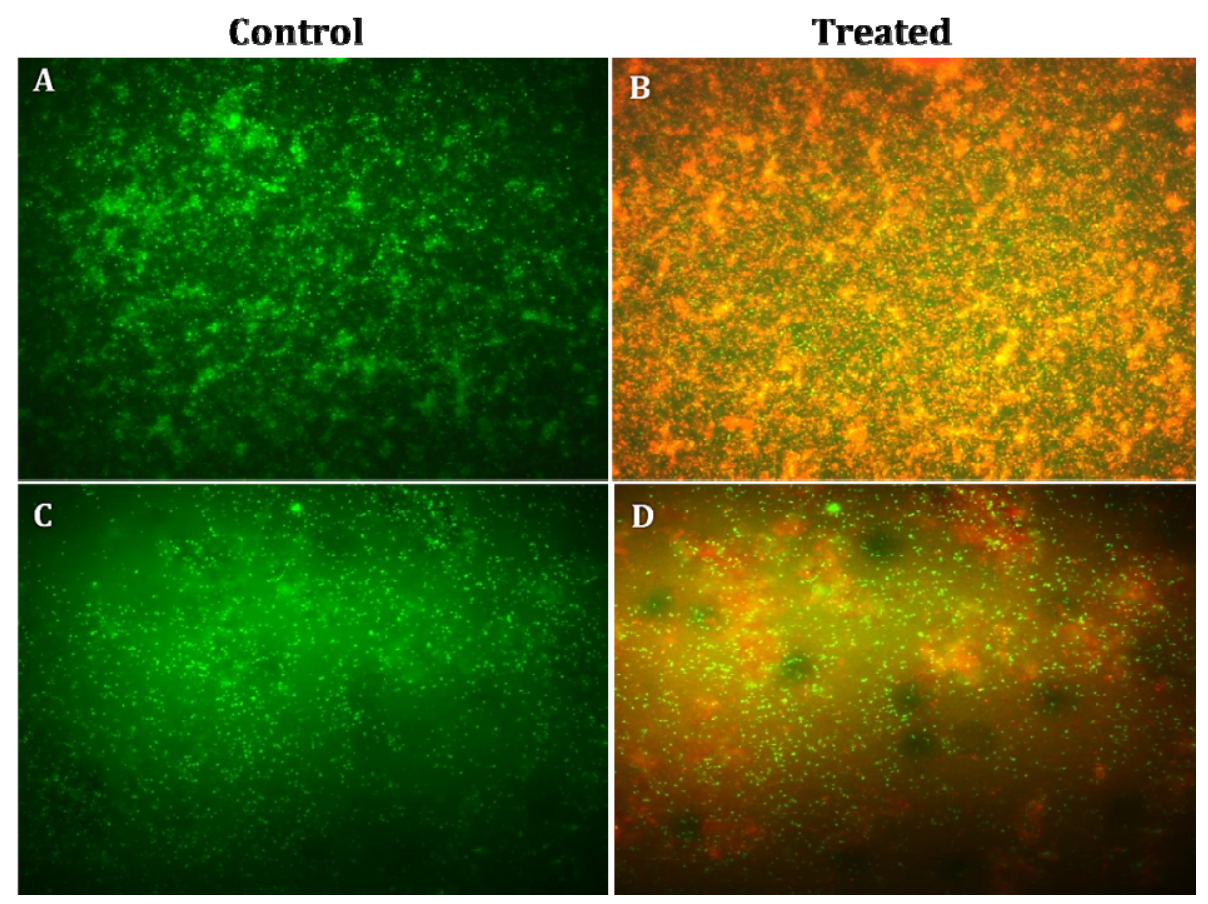

Figure 10. Fluorescence microscopy images of control and AgNP-treated Staphylococcus aureus and Ralstonia solanacearum: (A) control S. aureus; (B) S. aureus treated with silver nanoparticles; (C) control R. solanacearum; (D) R. solanacearum treated with silver nanoparticles. Green spots represent live bacterial cells, whereas red fluorescence indicates dead bacteria.
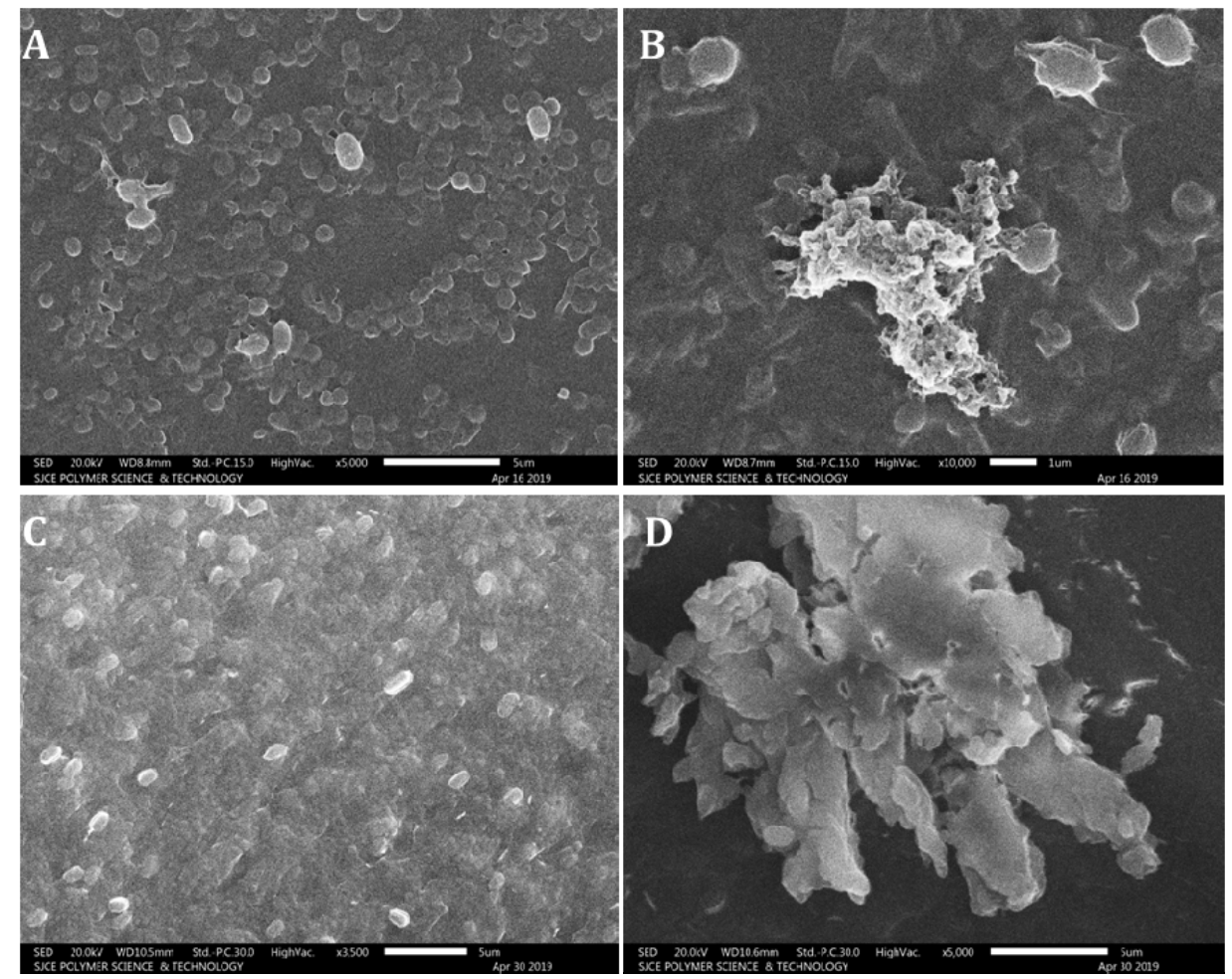

Figure 11. Scanning electron microscopy images of control and AgNP-treated Staphylococcus aureus and Ralstonia solanacearum: (A) control S. aureus; (B) S. aureus treated with silver nanoparticles; (C) control R. solanacearum; (D) R. solanacearum treated with silver nanoparticles. Silver nanoparticles cause morphological modification of bacterial cell structures. 


\section{Discussion}

The silver element and its mixtures are reported to have antimicrobial properties and have been used to store water or in the making of coins from times immemorial [35]. Silver nanoparticles exhibit effective antimicrobial activity compared to other NPs because of their great surface area and their interaction with microbial cell walls [36]. In the present study, chemical constituents in the culture filtrate of T. harzianum were determined using LC-MS/MS [29-34]. The details of all the compounds identified in the T. harzianum culture filtrate are presented in Table 1. The different bioactive metabolites belonging to the groups of flavanones, steroids, alkaloids and phospholipids were detected using high-performance liquid chromatography coupled with tandem mass spectrometry (LC-MS/MS). The compounds were identified as 1-benzoyl-3-[(S)-((2DS, 4R, 8R)-8ethylquinuclidin-2-yl](6-methoxyquinolin-4-yl)methyl)thiourea $(\mathrm{m} / \mathrm{z}$ 489.2323), puerarin $(m / z$ 416.2064), genistein $(m / z$ 432.2986), isotalatizidine $(m / z$ 407.2975) and ginsenoside $(m / z$ 800.5387). These compounds belong to the phytochemical groups of flavanones, terpenoids, steroids and alkaloids. These metabolites exhibit vast biological activities and were reported earlier to exhibit antibacterial, antimicrobial, antioxidant and anticancer properties. Puerarin is used in treating ailments such as fever, diarrhea, toxicosis and metabolic disorders. It is also reported to possess antibacterial, antioxidant and anticarcinogenic activities (Table 1). Genistein, naturally occurring in the human diet, has potent antioxidant, anticancer and antiosteoporosis effects (Table 1). Isotalatizidine and Ginsenoside have been reported to be useful as antibacterial and antifungal agents (Table 1). The previous research reports prove the efficient antimicrobial and antioxidant properties of the bioactive metabolites associated with $T$. harzianum filtrate. The fungal metabolites that are responsive for reducing and/or capping agents were subjected to the reduction of $\mathrm{Ag}^{+}$ions to $\mathrm{Ag}^{0}$ metal for the biosynthesis and fabrication of AgNPs from T. harzianum filtrate [37].

In the present study, biosynthesized AgNPs from T. harzianum filtrate exhibited broadspectrum antibacterial activity, inhibiting Gram-positive and Gram-negative bacteria tested. The maximum zone of inhibition was obtained against $R$. solanacearum $(17.43 \mathrm{~mm})$, and the minimum zone of inhibition was obtained against B. subtilis $(13.86 \mathrm{~mm})$. Remarkably, the AgNPs synthesized using T. harzianum filtrate were found to be more active against the Gram-negative bacteria ( $R$. solanacearum and E. coli) than the Gram-positive bacteria (S. aureus and B. subtilis). This finding is in agreement with Liao et al. [38], who reported that Gram-negative bacteria are usually more susceptible to $\mathrm{Ag}^{+}$invasion compared to Gram-positive bacteria due to the difference in their cell wall structures. Trichoderma spp. are of vast economic importance due to their ability to produce several important enzymes and antimicrobial metabolites and their ability to act as potent biological control agents against many plant pathogens $[4,21,39,40]$.

Our findings are in accordance with those of Raza et al. [41], who reported that the AgNPs exhibited significant broad-spectrum antimicrobial properties and the bioactive concentration of AgNPs matched with commercially available antibiotic drugs. The antimicrobial properties of AgNPs against several pathogenic microorganisms are attributed to numerous key mechanisms [42]. The enhanced antibacterial activity of biosynthesized AgNPs is because of their identical shape, smaller size and limited size dispersal [43]. AgNPs attach to the negatively charged cell surface; modify the physical and chemical properties of the cell wall and the cell membranes; and interrupt significant functions such as osmoregulation, permeability, electron transport and respiration [44]. Following penetration, AgNPs enter into the cytoplasm of bacteria, and AgNPs can also disrupt the cellular function by interacting with enzymes and amino acids, forming reactive oxygen species (ROS) and disintegrating the bacterial DNA [38]. The colloidal consistency of the AgNPs easily captures the bacteria, thus enhancing their interaction and entry into the cell wall [45]. The silver ions interact with diverse thiol groups of peptides/enzymes and DNA, thus interrupting DNA replication of microbes, causing structural modification and the development of granules of sulfur and interrupting the synthesis of cellular proteins and enzymes essential for ATP synthesis [46]. 
Previous research has proved that AgNPs synthesized from the culture filtrate of filamentous fungus T. harzianum and evaluated for their antibacterial activities against Staphylococcus aureus and Klebsiella pneumonia showed significant inhibition of bacterial growth in a dose-dependent manner, with the Gram-negative bacterium (K. pneumoniae) showing higher sensitivity [47]. Chen et al. [48] reported improved antibacterial effects of AgNPs using selected surfactants against the phytopathogenic bacterium Ralstonia solanacearum compared to silver ions with low MIC $(4.88 \mu \mathrm{g} / \mathrm{mL})$ and MBC $(19.5 \mu \mathrm{g} / \mathrm{mL})$. The AgNPs synthesized from $T$. harzianum filtrate resulted in dose-dependent death when they were tested against larvae and pupae of the dengue vector mosquito Aedes aegypti [49]. The green-synthesized AgNPs from Aspergillus niger showed activity against Xanthomonas citri and R. solanacearum [50].

In the present study, the green-synthesized AgNPs from fungi exhibited an absorbance range of $430-448 \mathrm{~nm}$ by UV-Vis spectrophotometer. The strong, single and wide surface plasmon resonance (SPR) peak obtained by UV-Vis spectrum indicated a polydispersity property of AgNPs [4]. The factors influencing the surface plasmon resonance (SPR) are the dielectric medium, particle size and chemical environment [8]. The appearance of brown color was due to excitation of SPR, which exhibited maximum absorbance in the visible range of 430-460 nm for AgNPs [51].

In the present study, the FT-IR analysis displayed major peaks for AgNPs with the highest intensity at $399.26 \mathrm{~cm}^{-1}$ matching to metal oxide (M-O). Our results are in accordance with the findings of Banerjee et al. [52], who reported the presence of alcohol, terpenoids and carbonyl groups providing support as tough binding spots for AgNPs by FT-IR analysis. Likewise, Vahabi et al. [53] reported the FT-IR spectrum from a drop coated film of an aqueous solution incubated with Trichoderma reesei and reacted with $\mathrm{Ag}^{+}$ions for $72 \mathrm{~h}$. The amide bonds identified at 1650 and $1450 \mathrm{~cm}^{-1}$ are due to $-\mathrm{C}=\mathrm{O}$ and $\mathrm{N}-\mathrm{H}$ stretch vibrations present in the amide linkages of the proteins, respectively. The images of green-synthesized AgNPs obtained from SEM exhibited identical crystalline structures aggregated closely with identical shape and morphology. The crystals of AgNPs exhibit maximum absorption at $3 \mathrm{keV}$ because of SPR [54]. The $\mathrm{C}$ and $\mathrm{Cl}$ accounted fora greater proportion of weight when compared to $\mathrm{O}$, which accounted for the least. The stability and strength of AgNPs are greatly influenced by the nature of crystals formed [55].

In the present study, the antioxidant activity of green-synthesized AgNPs was evaluated by DPPH free radical scavenging and FRAP assay. In the DPPH scavenging activity of AgNPs, the $\mathrm{IC}_{50}$ value was $0.79 \mathrm{mg} / \mathrm{mL}$. DPPH is a stable compound that becomes reduced by receiving electrons or hydrogen and thus is widely used to assess antioxidant activities. $\mathrm{IC}_{50}$ values are inversely associated with DPPH scavenging activity. The free radicals from metal stimulate oxidative stress; for example, reactive oxygen species (ROS) cause destruction of cell walls, DNA and mitochondria in bacteria, finally resulting in the death of the cell [56] (Figure 12). Trichoderma species stimulate the production of low-molecularweight and volatile compounds such asphytoalexins, harzianopyridone, pyrones, terpenes, peptaibols and terpenoid compounds that have antibacterial activity [57]. Certain Trichoderma species have been known as producers of significant secondary metabolites such as plant growth regulators, antibiotics and enzymes that mostly are used to protect plants from pathogens [58]. Enzymes secreted by the Trichoderma species are known to have antimicrobial, anticancer and antioxidant activity [59]. 


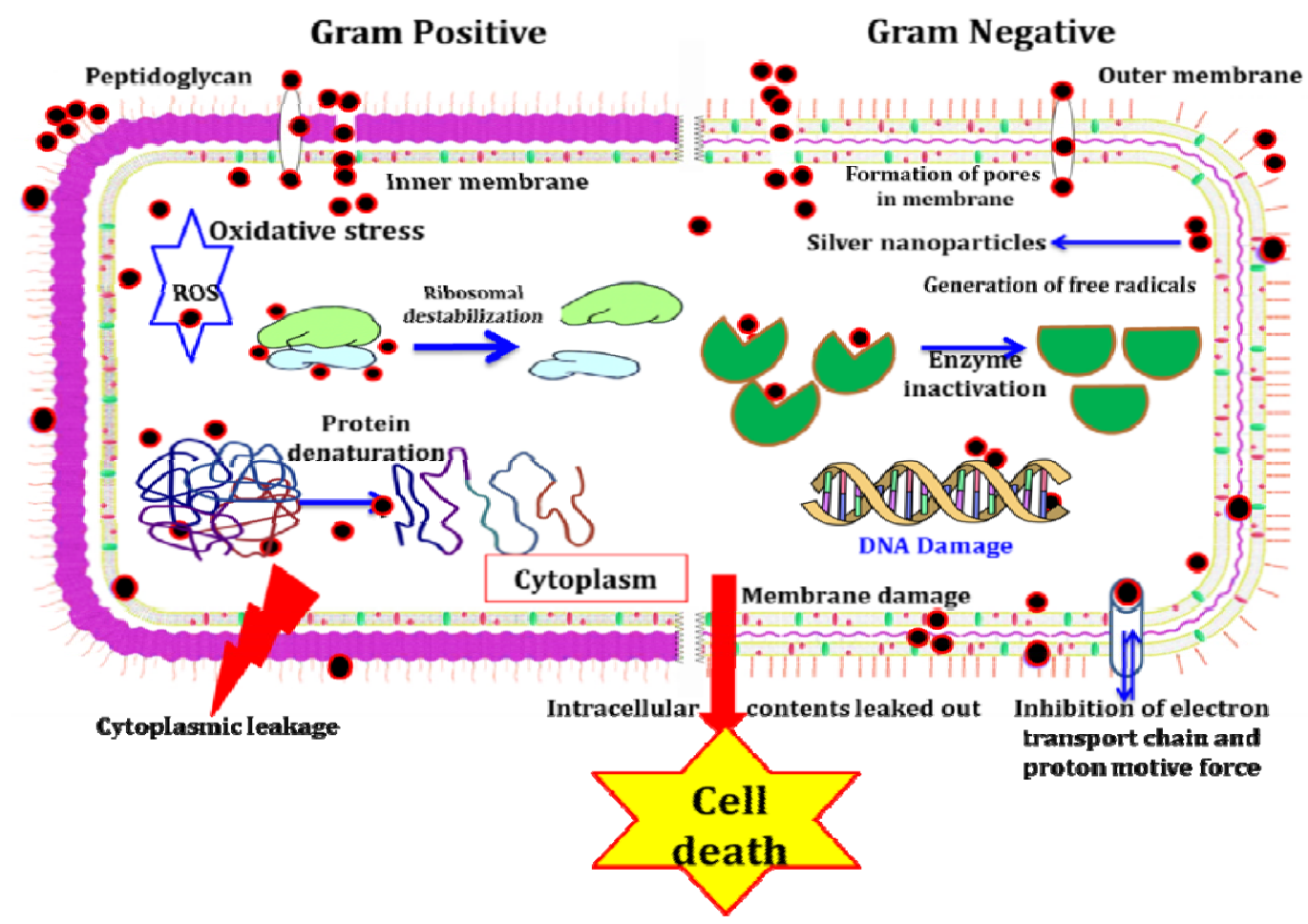

Figure 12. Proposed various modes of action of silver nanoparticles against bacterial growth/proliferation.

\section{Conclusions}

The field of nanotechnology has been a significantly growing area of research in recent years, as it has immense applications in healthcare, industries and environmental fields. In the current study, the silver nanoparticles synthesized from T. harzianum culture filtrate were stable and exhibited useful bioactivities. The green-synthesized AgNPs exhibited broad-spectrum antibacterial activity against the Gram-positive and Gram-negative pathogenic bacteria tested; significant antioxidant properties were also detected. The method adopted in this study for green synthesis of AgNPs is rapid, economically viable, ecologically friendly, nontoxic and suitable for large-scale production. However, further research is required to demonstrate the other biological activities (e.g., antifungal, antidiabetic, anti-inflammatory and cytotoxic potential) and the mechanism of action.

Author Contributions: Designed the experiments and performed experiments, N.K., A.C.U., S.C. and S.J. (Sudisha Jogaiah); compilation of data, S.C., S.J. (Sudisha Jogaiah); software and data validation, N.K., S.C., S.D.B. and S.J. (Sudisha Jogaiah); structured and drafted the manuscript, N.K., N.D., F.U., S.J. (Shubha Jagannath), S.C., A.C.U. and S.J. (Sudisha Jogaiah); All authors reviewed and edited the manuscript. All authors have read and agreed to the published version of the manuscript.

Funding: This research received no external funding.

Institutional Review Board Statement: Not applicable.

Informed Consent Statement: Not applicable.

Acknowledgments: We are thankful forfacilities provided by the Department of Microbiology and Biotechnology, Bangalore University, Bengaluru, under UGC-SAP-II (DRS-II) Reference No. F.48/2018/DRS-II (SAP-II), dated 23 April 2018. All the authors would extend thanks to Laboratory of Plant Healthcare and Diagnostics, PG Department of Biotechnology and Microbiology, Karnatak University, Dharwad, for the research facilities.

Conflicts of Interest: The authors declare no conflict of interest. 


\section{References}

1. Sadeghi, B.; Rostami, A.; Momeni, S.S. Facile green synthesis of silver nanoparticles using seed aqueous extract of Pistacia atlantica and its antibacterial activity. Spectrochim. Acta Part A Mol. Biomol. Spectrosc. 2015, 134, 326-332. [CrossRef]

2. Guilger-Casagrande, M.; Lima, R. Synthesis of silver nanoparticles mediated by fungi: A Review. Front. Bioeng. Biotechnol. 2019, 7, 287. [CrossRef] [PubMed]

3. Edwards, B. Silver Nanoparticles: Advances in Research and Applications; Nova Science Publishers Inc.: Hauppauge, NY, USA, 2017.

4. Nandini, B.; Puttaswamy, H.; Prakash, H.S.; Adhikari, S.; Jogaiah, S.; Nagaraja, G. Elicitation of novel Trichogenic-lipid nanoemulsion signaling resistance against pearl millet downy mildew disease. Biomolecules 2020, 10, 25. [CrossRef]

5. Paramanya, A.; Sharma, S.; Bagdat, R.B.; Ali, A. Recent practices of medicinal and aromatic plants in nanotechnology. In Nanomaterials for Agriculture and Forestry Applications; Elsevier: London, UK, 2020; pp. 435-467.

6. Nartop, P. Effects of surface sterilisation with green synthesized silver nanoparticles on Lamiaceae seeds. IET Nanobiotechnol. 2018, 12, 663-668. [CrossRef]

7. Jogaiah, S.; Kurjogi, M.; Abdelrahman, M.; Nagabhushana, H.; Tran, L.-S.P. Ganoderma applanatum-mediated green synthesis of silver nanoparticles: Structural characterization and in vitro and in vivo biomedical and agrochemical properties. Arab. J. Chem. 2019, 12, 1108-1120. [CrossRef]

8. Nayak, S.; Meghashyama, P.B.; Udayashankar, A.C.; Lakshmeesha, T.R.; Geetha, N.; Jogaiah, S. Biosynthesis and characterization of Dilleniaindica-mediated silver nanoparticles and their biological activity. Appl. Organomet. Chem. 2019, 34, e5567. [CrossRef]

9. Elemike, E.E.; Fayemi, O.E.; Ekennia, A.C.; Onwudiwe, D.C.; Ebenso, E.E. Silver nanoparticles mediated by Costus afer leaf extract: Synthesis, antibacterial, antioxidant and electrochemical properties. Molecules 2017, 22, 701. [CrossRef] [PubMed]

10. Ahmad, H.; Venugopal, K.; Rajagopal, K.; De Britto, S.; Nandini, B.; Pushpalatha, H.G.; Konappa, N.; Udayashankar, A.C.; Geetha, N.; Jogaiah, S. Green Synthesis and characterization of zinc oxide nanoparticles using Eucalyptus globules and their fungicidal ability against pathogenic fungi of apple Orchards. Biomolecules 2020, 10, 425. [CrossRef]

11. Ji, H.; Zhou, S.; Fu, Y.; Wang, Y.; Mi, J.; Lu, T.; Wang, X.; Lü, C. Size-controllable preparation and antibacterial mechanism of thermo-responsive copolymer-stabilized silver nanoparticles with high antimicrobial activity. Mat. Sci. Eng. 2020, 110, 110735. [CrossRef]

12. Chen, D.; Li, X.; Soule, T.; Yorio, F.; Orr, L. Effects of solution chemistry on anti- microbial activities of silver nanoparticles against Gordonia sp. Sci. Total Environ. 2016, 566, 360-367. [CrossRef]

13. Durán, N.; Nakazato, G.; Seabra, A.B. Antimicrobial activity of biogenic silver nanoparticles, and silver chloride nanoparticles: An overview and comments. Appl. Microbiol. Biotechnol. 2016, 100, 6555-6570. [CrossRef]

14. Sastry, M.; Ahmad, A.; Islam, N.I.; Kumar, R. Biosynthesis of metal nanoparticles using fungi and actinomycete. Curr. Sci. 2003, 85, 162-170.

15. Patel, V.; Berthold, D.; Puranik, P.; Gantar, M. Screening of cyanobacteria and microalgae for their ability to synthesize silver nanoparticles with antibacterial activity. Biotechnol. Rep. 2015, 5, 112-119. [CrossRef] [PubMed]

16. Ortega, F.G.; Fernández-Baldo, M.A.; Fernández, J.G.; Serrano, M.J.; Sanz, M.I.; Diaz- Mochón, J.J.; Lorente, J.A.; Raba, J. Study of antitumor activity in breast cell lines using silver nanoparticles produced by yeast. Int. J. Nanomed. 2015, 10, 2021-2031. [CrossRef]

17. Pantidos, N.; Horsfall, L.E. Biological synthesis of metallic nanoparticles by bacteria, fungi and plants. J. Nanomed. Nanotechnol. 2014, 5, 233. [CrossRef]

18. Zhao, X.; Zhou, L.; RiazRajoka, M.S.; Yan, L.; Jiang, C.; Shao, D.; Zhu, J.; Shi, J.; Huang, Q.; Yang, H.; et al. Fungal silver nanoparticles: Synthesis, application and challenges. Crit. Rev. Biotechnol. 2018, 38, 817-835. [CrossRef] [PubMed]

19. Vijayan, S.; Divya, K.; George, T.K.; Jisha, M.S. Biogenic synthesis of silver nanoparticles using endophytic fungi Fusarium oxysporum isolated from Withania somnifera, its antibacterial and cytotoxic activity. J. Bionanosci. 2016, 10, 369-376. [CrossRef]

20. Zomorodian, K.; Pourshahid, S.; Sadatsharifi, A.; Mehryar, P.; Pakshir, K.; Rahimi, M.J.; Monfared, A.A. Biosynthesis and characterization of silver nanoparticles by Aspergillus species. BioMed Res. Int. 2016, 2016, 5435397. [CrossRef] [PubMed]

21. Guilger, C.M.; Tais, G.-C.; Stigliani, T.P.; Fraceto, L.F.; de Lima, R. Biosynthesis of silver nanoparticles employing Trichoderma harzianum with enzymatic stimulation for the control of Sclerotinia sclerotiorum. Sci. Rep. 2019, 9, 14351. [CrossRef]

22. Kamil, D.; Prameeladevi, T.; Ganesh, S.; Prabakharan, N.; Nareshkumar, R.; Thomas, S.P. Green synthesis of silver nanoparticles by entomopathogenic fungus Beauveria bassiana and their bioefficacy against mustard aphid (Lipaphis erysimi Kalt.). Indian J. Exp. Biol. 2017, 55, 555-561.

23. Singh, D.; Rathod, V.; Ninganagouda, S.; Jyothi, H.; Singh, A.K.; Mathew, J. Optimization and characterization of silver nanoparticle by endophytic fungi Penicillium sp. isolated from Curcuma longa (Turmeric) and application studies against MDR E. coli and S. aureus. Bioinorg. Chem. Appl. 2014, 2014, 408021. [CrossRef] [PubMed]

24. Balaji, D.S.; Basavaraja, S.; Deshpande, R.; Mahesh, D.B.; Prabhakar, B.K.; Venkataraman, A. Extracellular biosynthesis of functionalized silver nanoparticles by strains of Cladosporium cladosporioides fungus. Colloids Surf. B Biointerfaces 2009, 68, 88-92. [CrossRef] [PubMed]

25. Shimada, K.; Fujikawa, K.; Yahara, K.; Nakamura, T. Antioxidative properties of xanthan on the autoxidation of soybean oil in cyclodextrin emulsion. J. Agric. Food Chem. 1992, 40, 945-948. [CrossRef]

26. Pulido, R.; Bravo, L.; Sauro-Calixto, F. Antioxidant activity of dietary polyphenols as determined by a modified ferric reducing/antioxidant power assay. J. Agric. Food Chem. 2000, 48, 3396-3402. [CrossRef]

27. CLSI (Clinical and Laboratory Standards Institute). Approved Standard, 9th ed.; CLSI: Wayne, PA, USA, 2012. 
28. Cui, J.; Liang, Y.; Yang, D.; Liu, Y. Facile fabrication of rice husk based silicon dioxide nanospheres loaded with silver nanoparticles as a rice antibacterial agent. Sci. Rep. 2016, 6, 21423. [CrossRef] [PubMed]

29. Zhong, W.; Pasunooti, K.K.; Balamkundu, S.; Wong, Y.H.; Qianhui, N.; Gadi, V.; Gnanakalai, S.; Chionh, Y.H.; McBee, M.E.; Gopal, P.; et al. Thienopyrimidinone derivatives that inhibit bacterial tRNA (Guanine37-N1)-Methyltransferase (TrmD) by restructuring the active site with a Tyrosine-Flipping mechanism. J. Med. Chem. 2019, 62, 7788-7805. [CrossRef] [PubMed]

30. Tang, F.; Li, W.H.; Zhou, X.; Liu, Y.H.; Li, Z.; Tang, Y.S.; Kou, X.; Wang, S.D.; Bao, M.; Qu, L.D.; et al. Puerarin protects against Staphylococcus aureus-induced injury of human alveolar epithelial A549 cells via down regulating alpha-hemolysin secretion. Microb. Drug Resist. 2014, 20, 357-363. [CrossRef]

31. Zhou, Y.X.; Zhang, H.; Peng, C. Puerarin: A review of pharmacological effects. Phytother. Res. 2014, 28, 961-975. [CrossRef]

32. Islam, A.; Islam, M.S.; Uddin, M.N.; Hasan, M.M.I.; Akanda, M.R. The potential health benefits of the isoflavone glycoside genistin. Arch. Pharmacal. Res. 2020, 43, 395-408. [CrossRef]

33. Ahmad, M.; Ahmad, W.; Ahmad, M.; Zeeshan, M.; Obaidullah, S.F. Norditerpenoid alkaloids from the roots of Aconitum heterophyllum Wall with antibacterial activity. J. Enzyme Inhib. Med. Chem. 2008, 23, 1018-1022. [CrossRef]

34. Na, S.; Kim, J.H.; Rhee, Y.K.; Oh, S.W. Enhancing the antimicrobial activity of ginseng against Bacillus cereus and Staphylococcus aureus by heat treatment. Food Sci. Biotechnol. 2017, 27, 203-210. [CrossRef] [PubMed]

35. Devi, L.S.; Joshi, S.R. Ultra structures of silver nanoparticles biosynthesized using endophytic fungi. J. Micros. Ultrastr. 2015, 3, 29-37. [CrossRef]

36. Ibrahim, H.M. Green synthesis and characterization of silver nanoparticles using banana peel extract and their antimicrobial activity against representative microorganisms. J. Radiat. Res. Appl. Sci. 2015, 8, 265-275. [CrossRef]

37. Ronavari, A.; Kovacs, D.; Igaz, N.; Vagvolgyi, C.; Boros, I.M.; Konya, Z.; Pfeiffer, I.; Kiricsi, M. Biological activity of greensynthesized silver nanoparticles depends on the applied natural extracts: A comprehensive study. Int. J. Nanomed. 2017, 12, 871-883. [CrossRef]

38. Liao, C.; Li, Y.; Tjong, S.C. Bactericidal and cytotoxic properties of silver nanoparticles. Int. J. Mol. Sci. 2019, 20, 449. [CrossRef]

39. Narasimha Murthy, K.; Fazilath, U.; Srinivas, C. Induction of systemic resistance by Trichoderma asperellum against bacterial wilt of tomato caused by Ralstonia solanacearum. Int. J. Adv. Res. 2013, 1, 181-194.

40. Jogaiah, S.; Abdelrahman, M.; Tran, L.-S.P.; Ito, S.-I. Different mechanisms of Trichoderma virens-mediated resistance in tomato against Fusarium wilt involve the jasmonic and salicylic acid pathways. Mol. Plant Pathol. 2018, 19, 870-882. [CrossRef] [PubMed]

41. Raza, M.A.; Kanwal, Z.; Rauf, A.; Sabri, A.N.; Riaz, S.; Naseem, S. Size- and shape-dependent antibacterial studies of silver nanoparticles synthesized by wet chemical routes. Nanomaterials 2016, 6, 74. [CrossRef]

42. Chang, B.M.; Pan, L.; Lin, H.H.; Chang, H.C. Nanodiamond-supported silver nanoparticles as potent and safe antibacterial agents. Sci. Rep. 2019, 9, 13164. [CrossRef]

43. Nayak, D.; Ashe, S.; Rauta, P.R.; Kumari, M.; Nayak, B. Bark extract mediated green synthesis of silver nanoparticles: Evaluation of antimicrobial activity and antiproliferative response against osteosarcoma. Mat. Sci. Eng. C. 2016, 58, 44-52. [CrossRef]

44. Marambio-Jones, C.; Hoek, E.M.V. A review of the antibacterial effects of silver nanomaterials and potential implications for human health and the environment. J. Nanoparticle Res. 2010, 12, 1531-1551. [CrossRef]

45. Chudasama, B.; Vala, A.K.; Andhariya, N.; Mehta, R.V.; Upadhyay, R.V. Highly bacterial resistant silver nanoparticles: Synthesis and antibacterial activities. J. Nanoparticle Res. 2010, 12, 1677-1685. [CrossRef]

46. Agnihotri, S.; Mukherji, S.; Mukherji, S. Size-controlled silver nanoparticles synthesized over the range 5-100 nm using the same protocol and their antibacterial efficacy. RSC Adv. 2014, 4, 3974-3983. [CrossRef]

47. Ahluwalia, V.; Kumar, J.; Sisodia, R.; Shakil, N.A.; Walia, S. Green synthesis of silver nanoparticles by Trichoderma harzianum and their bio-efficacy evaluation against Staphylococcus aureus and Klebsiella pneumonia. Ind. Crops Prod. 2014, 55, 202-206. [CrossRef]

48. Chen, J.; Li, S.; Luo, J.; Wang, R.; Ding, W. Enhancement of the antibacterial activity of silver nanoparticles against phytopathogenic bacterium Ralstonia solanacearum by Stabilization. J. Nanomater. 2016, 2016, 7135852. [CrossRef]

49. Sundaravadivelan, C.; Padmanabhan, M.N. Effect of mycosynthesized silver nanoparticles from filtrate of Trichoderma harzianum against larvae and pupa of dengue vector Aedes aegypti L. Environ. Sci. Pollut. Res. 2014, 21, 4624-4633. [CrossRef] [PubMed]

50. Prameela Devi, T.; Kamil, D.; Toppo, R.S. Silver nanoparticles production by Aspergillus niger and their antibacterial efficacy against Xanthomonas citri and Ralstonia solanacearum. J. Environ. Biol. 2018, 39, 493-499. [CrossRef]

51. Tripathy, A.; Raichur, A.M.; Chandrasekaran, N.; Prathna, T.C.; Mukherjee, A. Process variables in biomimetic synthesis of silver nanoparticles by aqueous extract of Azadirachta indica (Neem) leaves. J. Nanoparticle Res. 2010, 12, 237-246. [CrossRef]

52. Banerjee, P.; Satapathy, M.; Mukhopahayay, A.; Das, P. Leaf extract mediated green synthesis of silver nanoparticles from widely available Indian plants: Synthesis, characterization, antimicrobial property and toxicity analysis. Bioresour. Bioprocess. 2014, 1, 3. [CrossRef]

53. Vahabi, K.; Mansoori, G.A.; Karimi, S. Biosynthesis of silver nanoparticles by fungus Trichoderma reesei. Insciences J. 2011, 1, 65-79. [CrossRef]

54. Bindhu, M.R.; Umadevi, M. Antibacterial and catalytic activities of green synthesized silver nanoparticles. Spectrochim. Acta Part A Mol. Biomol. Spectrosc. 2015, 135, 373-378. [CrossRef] [PubMed]

55. Jassal, V.; Shanker, U.; Gahlot, S.; Kaith, B.S.; Iqubal, M.A.; Samuel, P. Sapindus mukorossi mediated green synthesis of some manganese oxide nanoparticles interaction with aromatic amines. Appl. Phys. A 2016, 122, 271. [CrossRef] 
56. Tamboli, D.P.; Lee, D.S. Mechanistic antimicrobial approach of extracellularly synthesized silver nanoparticles against gram positive and gram negative bacteria. J. Hazard. Mater. 2013, 260, 878-884. [CrossRef] [PubMed]

57. Kubicek, C.P.; Machl, R.L.; Peterbauerl, C.K.; Lorito, M. Trichoderma: From genes to biocontrol. J. Plant Pathol. $2001,83,11-23$.

58. Respinis, S.D.; Vogel, G.; Benagli, C. MALDI-TOF MS of Trichoderma: Model system for the identification of microfungi. Mycol. Prog. 2010, 9, 79-100. [CrossRef]

59. Abd El-Rahman, A.A.; ElShafei, S.M.A.; Ivanova, E.V.; Fattakhova, A.N.; Pankova, A.V.; El-Shafei, M.A.; El-El-Morsi, M.A.; Alimova, F.K. Cytotoxicity of Trichoderma spp. cultural filtrate against humancervical and breast cancer cell lines. Asian Pac. J. Cancer Prev. 2014, 15, 7229-7234. [CrossRef] [PubMed] 